Article

\title{
Pt(II) Derivatives with Rollover-Coordinated 6-substituted 2,2'-bipyridines: Ligands with Multiple Personalities
}

\author{
Antonio Zucca ${ }^{1,2, *(\mathbb{D},}$, Luca Maidich ${ }^{1}$, Maria I. Pilo ${ }^{1}{ }^{\mathbb{D}}$, Sara Pischedda ${ }^{1}$, Mondina Sedda ${ }^{1}$ \\ and Sergio Stoccoro ${ }^{1,2}$ \\ 1 Dipartimento di Chimica e Farmacia, Università degli Studi di Sassari, via Vienna 2, 07100 Sassari, Italy; \\ luca.maidich@gmail.com (L.M.); mpilo@uniss.it (M.I.P.); sarapischedda.sp@gmail.com (S.P.); \\ mondina89@tiscali.it (M.S.); stoccoro@uniss.it (S.S.) \\ 2 Consorzio Interuniversitario Reattività Chimica e Catalisi (CIRCC), 70126 Bari, Italy \\ * Correspondence: zucca@uniss.it
}

Received: 24 August 2020; Accepted: 20 September 2020; Published: 23 September 2020

check for updates

Featured Application: The new rollover complexes and the study of their reactivity could have various potential applications such as photo-responsive devices, antitumor agents, and catalytic processes (e.g., hydrogen transfer reactions).

\begin{abstract}
We report here the synthesis, characterization and behavior of a series of $\mathrm{Pt}(\mathrm{II})$ cyclometalated rollover complexes with two substituted bipyridines, 6-ethyl-2,2' -bipyridine (bpy ${ }^{6 \mathrm{Et}}$ ) and 6-methoxy-2,2'-bipyridine (bpy $\left.{ }^{6 \mathrm{OMe}}\right)$, in comparison with previously studied 2,2'-bipyridine complexes. The two ligands have similar steric hindrance but different electronic properties. As a result, the reactivity of the two series of complexes follows very different routes. In particular, the new complexes behave differently towards protonation reactions, differences given by substituents and ancillary ligands, added to the presence of several nucleophilic centers. Reaction of complex $\left.\left[\mathrm{Pt}\left(\mathrm{bpy}^{6 \mathrm{OMe}}-\mathrm{H}\right)\left(\mathrm{PPh}_{3}\right) \mathrm{Me}\right)\right]$ with $\left[\mathrm{H}_{3} \mathrm{O} \cdot 18\right.$-crown-6] $\left[\mathrm{BF}_{4}\right]$ results in a retro-rollover reaction whose final product is the cationic adduct $\left.\left[\mathrm{Pt}\left(\mathrm{bpy}^{6 \mathrm{OMe}}\right)\left(\mathrm{PPh}_{3}\right) \mathrm{Me}\right)\right]^{+}$. Surprisingly, only the isomer with the cis- $\mathrm{PPh}_{3}-\mathrm{OMe}$ geometry is formed; in spite of an expected instability due to steric hindrance, Density-Functional theory (DFT) calculations showed that this isomer is the most stable. This result shows that the cone angle is far from being a real "solid cone" and should lead to a different interpretation of well-known concepts concerning steric bulk of ligands, such as cone angle. Proton affinity values of ligands, neutral complexes and their protonated counterparts were analyzed by means of DFT calculations, allowing a comparison of their properties.
\end{abstract}

Keywords: cyclometalated compounds; rollover cyclometalation; bipyridines

\section{Introduction}

Cyclometalated complexes constitute an important class of organometallic compounds owing to their intrinsic stability and the wide range of their potential applications [1-3]. Among the ample variety of cyclometalated compounds, the so-called rollover complexes constitute a special and intriguing case due to their peculiar properties [4-6].

The differences between the classical and rollover cyclometalated compounds at a first sight may appear trivial; however, they are, as a matter of fact, substantial. The first difference which connotes the rollover subclass resides in the $\mathrm{C}-\mathrm{H}$ bond activation process which generates the complexes: classical cyclometallation needs simple coordination of a monodentate ligand, followed by $\mathrm{C}-\mathrm{H}$ bond activation and metalation; at variance, the rollover process needs a bidentate heterocyclic ligand, which may 
"choose" between a classical chelation or cyclometallation (see Scheme 1). Usually the first act is the formation of a chelated complex, followed by decoordination of one of the donor atoms, internal rotation of the heteroaromatic rings and, finally, a "remote" C-H bond activation (Scheme 1) $[7,8]$. As reported by Skapski, Sutcliffe and Young in their precursor work on rollover cyclometalation (where they coined the term "roll-over cyclometalation") [7], metalation is faster for Pt(II) electron-rich starting complexes. An oxidative addition of the $\mathrm{C}(3)-\mathrm{H}$ bond followed by reductive elimination of methane is a likely reaction pathway.

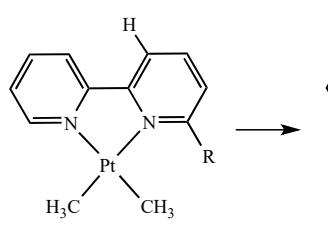

A

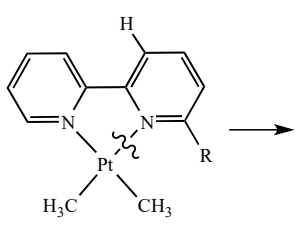

B

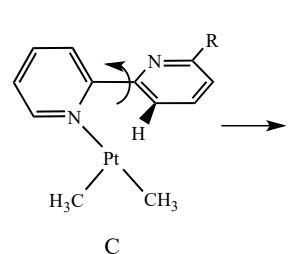

C

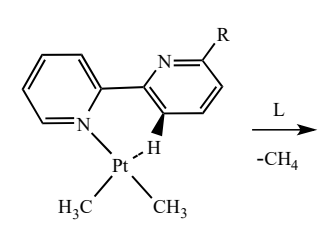

$\mathrm{D}$

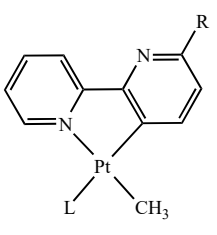

E

Scheme 1. Rollover cyclometalation of 6-substituted 2,2'-bipyridines with by $\mathrm{Pt}(\mathrm{II})$.

2-Phenylpyridine and 2,2'-bipyridine are common examples of ligands able to give classical and rollover cyclometalated complexes, as depicted in Figure 1.

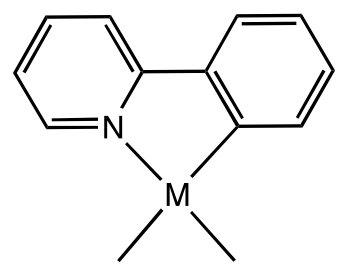

classical cyclometalated complex (2-phenyl-pyridine)

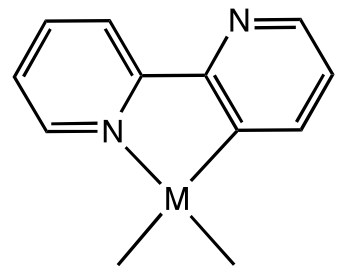

rollover cyclometalated complex $(2,2$ '-bipyridine $)$

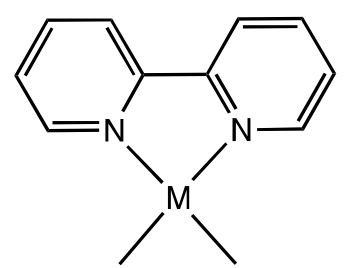

classical chelated complex $(2,2$ '-bipyridine)

Figure 1. Coordination modes of 2-Phenylpyridine and 2,2'-bipyridine.

A first consequence of the difference between the two classes of organometallic species is that the rollover process is reversible in nature by means of protonation, leading to noteworthy applications, e.g., in catalysis [9-19].

A second important difference between the two subclasses is given by the uncoordinated donor atom, usually a nitrogen, able to act as a Lewis base and hence influence the reactivity and properties of the complex, by means of coordination, protonation, interactions and, as stated above, reversibility of the rollover process. For such reasons, these "rollover" ligands belong to the interesting category of "ligands with multiple personalities" [20]. Protonation of the uncoordinated nitrogen transforms the rollover-cyclometalated 2,2'-bipyridine, formally an anionic ligand, into a neutral mesoionic ligand, an abnormal-remote pyridylene ligand [21-25].
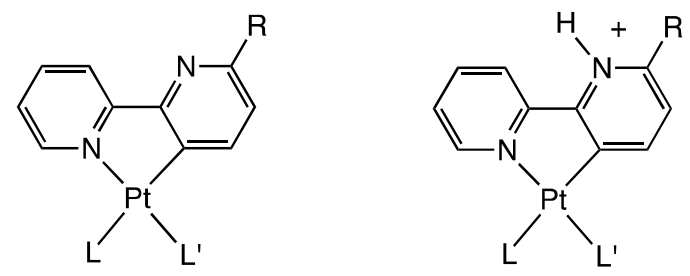

$L, L^{\prime}=$ neutral or anionic ligands 
Due to their intriguing peculiarities, rollover complexes are attracting a growing interest in recent years, as demonstrated by the rising number of papers, among which some have recent reviews $[4,26,27]$. The interest is focused on the reactivity of these species [28-31] and to applications in organic synthesis [32-35] and catalysis [9-19], as well as chemosensors [36], luminescent devices [37], and potent antitumor agents [38-43].

Even though a large number of studies have been dedicated to 2,2'-bipyridine and its derivatives, the reaction is not so restricted and has a general interest being applicable to an ample variety of bidentate heterocyclic donors [44,45].

As a part of the ongoing work in our laboratory exploring this field [46-50] we report here the comparison between platinum(II) rollover derivatives of 6-ethyl- and 6-methoxy-2,2'-bipyridine, where the different properties of the substituents deeply influence the reactivity of the corresponding cyclometalated complexes.

\section{Materials and Methods}

All the solvents were purified and dried according to standard procedures [51]. The starting complex cis-[Pt(Me $\left.)_{2}(\mathrm{DMSO})_{2}\right]$ was synthesized according to reference [52-54].

The ligands 6-methoxy-2,2'-bipyridine $\left(\mathrm{bpy}^{6 \mathrm{OMe}}\right)$ and 6-ethyl-2,2'-bipyridine $\left(\mathrm{bpy}^{6 \mathrm{Et}}\right)$ were prepared by Suzuki-Miyaura couplings [55].

Elemental analyses were performed with a Perkin-Elmer elemental analyzer $240 \mathrm{~B}$ at the Department of Chemistry and Pharmacy of the University of Sassari.

${ }^{1} \mathrm{H}$ and ${ }^{31} \mathrm{P}$ NMR spectra were recorded with a Bruker Avance III 400 spectrometer operating at 400.0 and $161.8 \mathrm{MHz}$, respectively. Chemical shifts are given in ppm relative to internal TMS for ${ }^{1} \mathrm{H}$ and external $85 \% \mathrm{H}_{3} \mathrm{PO}_{4}$ for ${ }^{31} \mathrm{P}$; J values are given in $\mathrm{Hz}$. Two dimensional ${ }^{1} \mathrm{H}$ COSY and NOESY spectra were performed by means of standard pulse sequences.

UV-Vis spectra were recorded in a $\mathrm{CH}_{2} \mathrm{Cl}_{2}$ solution of each complex using a Fulltech T80+ spectrophotometer.

Electrochemical tests were performed with a computerized electrochemical system $\mathrm{CHI}-650(\mathrm{CH}$ Instruments, Austin, TX, USA) using its specific software. A single-compartment, three-electrode cell was used. A $2 \mathrm{~mm}$ diameter Pt disk was used as a working electrode, an aqueous $\mathrm{Ag} / \mathrm{AgCl}$ with a suitable salt bridge was the reference electrode, and a graphite rod was the auxiliary electrode. All the experiments were carried out in $\mathrm{CH}_{2} \mathrm{Cl}_{2}$ solvent (anhydrous, $\geq 99.8 \%$ ), using tetraethylammonium hexafluorophosphate $\left(\mathrm{TEAPF}_{6}\right.$, for electrochemical analysis, $\geq 99.0 \%$ ) as the supporting electrolyte, under Ar atmosphere and at room temperature, using a potential scan rate equal to $100 \mathrm{mV} \mathrm{s}^{-1}$.

\subsection{DFT Calculations}

DFT calculations were carried out using the PBE0 hybrid functional developed by Perdew, Burke and Ernzerhof [56,57] and modified in its hybrid version by Adamo and Barone [58] with ZORA (Zeroth order regular approximation) [59-62] using the ZORA-def2-SVP basis set for all atoms except for $\mathrm{Pt}$ for which we used a segmented all-electron relativistically contracted (SARC) basis set [63] along with the RI-JONX approximation as implemented in the ORCA 4.2.1 package [64,65]. Harmonic analysis at the same level of theory was carried out on the equilibrium geometries to confirm the nature of the minimum (i.e., the absence of imaginary frequencies) on the PES (Potential energy surface).

\subsection{Preparations}

Compounds 1a and 6a were prepared as described in reference [66].

\section{3. $\left[P t\left(b p y^{6 E t}-H\right)(M e)(D M S O)\right], \mathbf{1 b}$}

To a stirred solution of bpy ${ }^{6 \mathrm{Et}}(115.2 \mathrm{mg}, 0.6252 \mathrm{mmol})$ in acetone $(15 \mathrm{~mL})$, solid [Pt(Me $)_{2}(\mathrm{DMSO})_{2}$ ] ( $227.6 \mathrm{mg}, 0.5967 \mathrm{mmol}$ ) was added under argon atmosphere. The orange solution was stirred and 
heated to $55{ }^{\circ} \mathrm{C}$ for two hours. The resulting solution was concentrated to a small volume under reduced pressure and treated with $n$-pentane. The precipitate formed was filtered off and washed with $n$-pentane to give the analytical sample as a yellow solid. Yield: $85 \%$. M.p. $=148{ }^{\circ} \mathrm{C}$. Anal. Calcd. for $\mathrm{C}_{15} \mathrm{H}_{20} \mathrm{~N}_{2} \mathrm{OSPt}$ : C, 38.21\%, H, 4.27\%, N, 5.09\%. Found C, 38.45\%, H, 4.61\%, N, 5.02\%. ${ }^{1} \mathrm{H}$ NMR $\left(\mathrm{CDCl}_{3}\right): \delta=0.69$ (s with sat, $\left.3 \mathrm{H},{ }^{2} \mathrm{~J}_{\mathrm{Pt}-\mathrm{H}}=82.3 \mathrm{~Hz}, \mathrm{Pt}-\mathrm{CH}_{3}\right) ; 1.32\left(\mathrm{t}, 3 \mathrm{H}, \mathrm{J}_{\mathrm{H}-\mathrm{H}}=7.5 \mathrm{~Hz}, \mathrm{CH}_{3} \mathrm{Et}\right) ; 2.79$ $\left(\mathrm{q}, 2 \mathrm{H}, \mathrm{J}_{\mathrm{H}-\mathrm{H}}=7.5 \mathrm{~Hz}, \mathrm{CH}_{2} \mathrm{Et}\right.$ ); 3.24 (s with sat, $6 \mathrm{H},{ }^{3} \mathrm{JPt}_{\mathrm{Pt}}=18.1 \mathrm{~Hz}, \mathrm{DMSO}$ ); 7.04 (d with sat, $1 \mathrm{H}, \mathrm{J}_{\mathrm{H}-\mathrm{H}}=$ $\left.7.9 \mathrm{~Hz}, \mathrm{~J}_{\mathrm{H}-\mathrm{H}}=16.8 \mathrm{~Hz}, \mathrm{H}_{5}\right) ; 7.32\left(\mathrm{ddd}, 1 \mathrm{H}, \mathrm{J}_{\mathrm{H}-\mathrm{H}}=1.6 \mathrm{~Hz}, \mathrm{~J}_{\mathrm{H}-\mathrm{H}}=5.7 \mathrm{~Hz}, \mathrm{~J}_{\mathrm{H}-\mathrm{H}}=7.5 \mathrm{~Hz}, \mathrm{H}_{5^{\prime}}\right) ; 7.90(\mathrm{t}, 1 \mathrm{H}$, $\left.\mathrm{J}_{\mathrm{H}-\mathrm{H}}=7.7 \mathrm{~Hz}, \mathrm{H}_{4^{\prime}}\right) ; 7.92\left(\mathrm{~d}\right.$ with sat, $\left.1 \mathrm{H},{ }^{3} \mathrm{~J}_{\mathrm{Pt}-\mathrm{H}}=53 \mathrm{~Hz}, \mathrm{~J}_{\mathrm{H}-\mathrm{H}}=7.8 \mathrm{~Hz} \mathrm{H}_{4}\right) ; 8.34\left(\mathrm{~d}, 1 \mathrm{H}, \mathrm{J}_{\mathrm{H}-\mathrm{H}}=7.9 \mathrm{~Hz}\right.$, $\mathrm{H}_{3^{\prime}}$ ); 9.67 (d with sat, $1 \mathrm{H}, \mathrm{J}_{\mathrm{H}-\mathrm{H}}=5.7 \mathrm{~Hz},{ }^{3} \mathrm{~J}_{\mathrm{Pt}-\mathrm{H}}=13.6 \mathrm{~Hz}, \mathrm{H}_{6^{\prime}}$ ).

\section{4. [.Pt $\left.\left(b p y^{6 E t *}\right)(M e)(D M S O)\right]\left[B F_{4}\right], 3 \mathbf{b}-B F_{4}$}

To a solution of $\mathbf{1 b}(50.0 \mathrm{mg}, 0.106 \mathrm{mmol})$ in acetone $(15 \mathrm{~mL})$, solid $\left[\mathrm{H}_{3} \mathrm{O} \cdot 18\right.$-crown-6] [ $\left.\mathrm{BF}_{4}\right]$ was added $(41.2 \mathrm{mg}, 0.113 \mathrm{mmol})$. The solution was stirred at room temperature for $2 \mathrm{~h}$, then it was concentrated to a small volume and treated with diethyl ether. The precipitate formed was filtered off and washed with diethyl ether to give the analytical sample as a yellow solid. Yield: 70\%. Anal. Calcd. for $\mathrm{C}_{15} \mathrm{H}_{21} \mathrm{~N}_{2} \mathrm{BF}_{4} \mathrm{OSPt}$ : C, 32.21\%, H, 3.78\%, N, 5.01\%. Found C, 31.94\%, H, 3.55; N, 5.31\%. ${ }^{1} \mathrm{H}$ NMR $\left(\mathrm{CDCl}_{3}\right): \delta=0.76$ (s with sat, $3 \mathrm{H}, \mathrm{J}_{\mathrm{Pt}-\mathrm{H}}=80.8 \mathrm{~Hz}, \mathrm{CH}_{3}-\mathrm{Pt}$ ); $1.46\left(\mathrm{t}, 3 \mathrm{H}, \mathrm{J}_{\mathrm{H}-\mathrm{H}}=7.6 \mathrm{~Hz}, \mathrm{CH}_{3} \mathrm{Et}\right) ; 3.22$ $\left(\mathrm{q}, 2 \mathrm{H}, \mathrm{J}_{\mathrm{H}-\mathrm{H}}=7.6 \mathrm{~Hz}, \mathrm{CH}_{2} \mathrm{Et}\right.$ ); 3.29 (s with sat, $6 \mathrm{H},{ }^{3} \mathrm{~J}_{\mathrm{Pt}-\mathrm{H}}=20.3 \mathrm{~Hz}, \mathrm{DMSO}$ ); 7.53 (d with sat, $1 \mathrm{H}, \mathrm{J}_{\mathrm{H}-\mathrm{H}}$ $\left.=8.2 \mathrm{~Hz},{ }^{4} \mathrm{Jt}_{\mathrm{Pt}-\mathrm{H}}=16.7 \mathrm{~Hz}, \mathrm{H}_{5}\right) ; 7.62\left(\mathrm{dd}, 1 \mathrm{H}, \mathrm{J}_{\mathrm{H}-\mathrm{H}}=5.7,7.7 \mathrm{~Hz}, \mathrm{H}_{5^{\prime}}\right) ; 8.27\left(\mathrm{t}, 1 \mathrm{H}, \mathrm{J}_{\mathrm{H}-\mathrm{H}}=7.8 \mathrm{~Hz}, \mathrm{H}_{4^{\prime}}\right)$; $8.62\left(\mathrm{~d}\right.$ with sat, $\left.1 \mathrm{H}, \mathrm{J}_{\mathrm{H}-\mathrm{H}}=8.2 \mathrm{~Hz},{ }^{3} \mathrm{~J}_{\mathrm{Pt}-\mathrm{H}}=57 \mathrm{~Hz}, \mathrm{H}_{4}\right) ; 8.74\left(\mathrm{~d}, 1 \mathrm{H}, \mathrm{J}_{\mathrm{H}-\mathrm{H}}=7.9 \mathrm{~Hz}, \mathrm{H}_{3^{\prime}}\right) ; 9.90$ (d with sat, $\left.1 \mathrm{H}, \mathrm{J}_{\mathrm{H}-\mathrm{H}}=5.7 \mathrm{~Hz},{ }^{3} \mathrm{~J}_{\mathrm{Pt}-\mathrm{H}}=12.5 \mathrm{~Hz}, \mathrm{H}_{6^{\prime}}\right) ; 13.30(\mathrm{~s} \mathrm{br}, \mathrm{N}-\mathrm{H})$.

\section{5. $\left[\mathrm{Pt}\left(\mathrm{bpy} \mathrm{y}^{6 \mathrm{OMe}}-\mathrm{H}\right)(\mathrm{Cl})(\mathrm{DMSO})\right], \mathbf{4}$}

To a stirred solution of bpy ${ }^{6 \mathrm{OMe}}(151.5 \mathrm{mg}, 0.8136 \mathrm{mmol})$ in acetone $(25 \mathrm{~mL})$, solid $\left[\mathrm{Pt}(\mathrm{Me})_{2}(\mathrm{DMSO})_{2}\right](295.5 \mathrm{mg}, 0.7747 \mathrm{mmol})$ was added. The solution was heated under argon atmosphere for $2 \mathrm{~h}$ at $45^{\circ} \mathrm{C}$, then it was cooled to room temperature and $0.1 \mathrm{M} \mathrm{HCl}(8.5 \mathrm{~mL}, 0.85 \mathrm{mmol})$ was added. The solution was stirred at room temperature for $5 \mathrm{~h}$, then it was evaporated until dry under reduced pressure and treated with acetone and $n$-pentane. The precipitate formed was filtered off and washed with $n$-pentane to give the analytical sample. Yield: $95 \%$. M.p. $=226^{\circ} \mathrm{C}$. Anal. Calcd. for $\mathrm{C}_{13} \mathrm{H}_{15} \mathrm{~N}_{2} \mathrm{ClO}_{2} \mathrm{SPt}$ : C, 31.62\%, H, 3.67\%, N, 5.67\%. Found C, 31.76\%, H, 3.45; N, 5.91\%. ${ }^{1} \mathrm{H}$ NMR $\left(\mathrm{CDCl}_{3}\right): \delta=3.63$ (s with sat, $\left.6 \mathrm{H},{ }^{3} \mathrm{~J}_{\mathrm{Pt}-\mathrm{H}}=23.6 \mathrm{~Hz}, \mathrm{DMSO}\right) ; 3.97(\mathrm{~s}, 3 \mathrm{H}, \mathrm{OMe}) ; 6.63$ (d with sat, $1 \mathrm{H}, \mathrm{J}_{\mathrm{H}-\mathrm{H}}$ $\left.=8.6 \mathrm{~Hz},{ }^{4} \mathrm{~J}_{\mathrm{Pt}-\mathrm{H}}=14.4 \mathrm{~Hz}, \mathrm{H}_{5}\right) ; 7.34\left(\mathrm{ddd}, 1 \mathrm{H}, \mathrm{J}_{\mathrm{H}-\mathrm{H}}=1.5 \mathrm{~Hz}, \mathrm{~J}_{\mathrm{H}-\mathrm{H}}=5.8 \mathrm{~Hz}, \mathrm{~J}_{\mathrm{H}-\mathrm{H}}=7.4 \mathrm{~Hz}, \mathrm{H}_{5^{\prime}}\right) ; 7.93(\mathrm{td}$, $\left.1 \mathrm{H}, \mathrm{J}_{\mathrm{H}-\mathrm{H}}=1.6 \mathrm{~Hz}, \mathrm{~J}_{\mathrm{H}-\mathrm{H}}=7.9 \mathrm{~Hz}, \mathrm{H}_{4^{\prime}}\right) ; 8.12\left(\mathrm{dd}, 1 \mathrm{H}, \mathrm{J}_{\mathrm{H}-\mathrm{H}}=1.0 \mathrm{~Hz}, \mathrm{~J}_{\mathrm{H}-\mathrm{H}}=7.9 \mathrm{~Hz}, \mathrm{H}_{3^{\prime}}\right) ; 8.47$ (d with sat, $\left.1 \mathrm{H}, \mathrm{J}_{\mathrm{H}-\mathrm{H}}=8.6 \mathrm{~Hz},{ }^{3} \mathrm{~J}_{\mathrm{Pt}-\mathrm{H}}=39.8 \mathrm{~Hz}, \mathrm{H}_{4}\right) ; 9.53$ (d with sat, $1 \mathrm{H}, \mathrm{J}_{\mathrm{H}-\mathrm{H}}=5.8 \mathrm{~Hz},{ }^{3} \mathrm{JPt}_{\mathrm{Pt}}=36.6 \mathrm{~Hz}, \mathrm{H}_{6^{\prime}}$ ).

\section{6. $\left[P t\left(b p y^{6 E t}-H\right)(C l)(D M S O)\right], 4 \mathbf{b}$}

Complex $4 \mathrm{~b}$ was obtained as complex $4 \mathrm{a}\left(55^{\circ} \mathrm{C}, 2 \mathrm{~h}\right)$, using bpy ${ }^{6 \mathrm{Et}}$ in place of bpy ${ }^{6 \mathrm{OMe}}$. Yield: $85 \%$. M.p. $=178{ }^{\circ} \mathrm{C}$. Anal. Calc. per $\mathrm{C}_{14} \mathrm{H}_{17} \mathrm{~N}_{2} \mathrm{ClOSPt}$ : C, 34.19\%, H, 3.48\%, N, 5.69\%. Found: $\mathrm{C}$, $33.87 \%, \mathrm{H}, 3.35 \%, \mathrm{~N}, 5.78 \% .{ }^{1} \mathrm{H}$ NMR $\left(\mathrm{CDCl}_{3}\right): \delta=1.32\left(\mathrm{t}, 3 \mathrm{H}, \mathrm{J}_{\mathrm{H}-\mathrm{H}}=7.5 \mathrm{~Hz}, \mathrm{CH}_{3} \mathrm{Et}\right) ; 2.77\left(\mathrm{q}, 2 \mathrm{H}, \mathrm{J}_{\mathrm{H}-\mathrm{H}}\right.$ $=7.5 \mathrm{~Hz}, \mathrm{CH}_{2} \mathrm{Et}$ ); 3.64 (s with sat, $6 \mathrm{H},{ }^{3} \mathrm{~J}_{\mathrm{Pt}-\mathrm{H}}=23.3 \mathrm{~Hz}, \mathrm{DMSO}$ ); 6.96 (d with sat, $1 \mathrm{H}, \mathrm{J}_{\mathrm{H}-\mathrm{H}}=8.2 \mathrm{~Hz}$, $\left.{ }^{4} \mathrm{~J}_{\mathrm{Pt}-\mathrm{H}}=15.6 \mathrm{~Hz}, \mathrm{H}_{5}\right) ; 7.36\left(\mathrm{~m}, 1 \mathrm{H}, \mathrm{J}_{\mathrm{H}-\mathrm{H}}=5.7,7.7 \mathrm{~Hz}, \mathrm{H}_{5^{\prime}}\right) ; 7.95\left(\mathrm{t}, 1 \mathrm{H}, \mathrm{J}_{\mathrm{H}-\mathrm{H}}=7.7 \mathrm{~Hz}, \mathrm{H}_{4^{\prime}}\right) ; 8.26(\mathrm{~d}, 1 \mathrm{H}$, $\left.\mathrm{J}_{\mathrm{H}-\mathrm{H}}=7.7 \mathrm{~Hz}, \mathrm{H}_{3^{\prime}}\right) ; 8.47$ (d with sat, $\left.1 \mathrm{H}, \mathrm{J}_{\mathrm{H}-\mathrm{H}}=8.2 \mathrm{~Hz},{ }^{3} \mathrm{~J}_{\mathrm{Pt}-\mathrm{H}}=25 \mathrm{~Hz}, \mathrm{H}_{4}\right) ; 9.56$ (d with sat, $1 \mathrm{H}, \mathrm{J}_{\mathrm{H}-\mathrm{H}}=$ $\left.\mathrm{J}_{\mathrm{H}-\mathrm{H}}=5.7 \mathrm{~Hz},{ }^{3} \mathrm{~J}_{\mathrm{Pt}-\mathrm{H}}=37 \mathrm{~Hz}, \mathrm{H}_{6^{\prime}}\right)$.

\section{7. [.Pt $\left.\left(b p y^{6 E t *}\right)(C l)(D M S O)\right]\left[B F_{4}\right], 5 \mathbf{b}-B F_{4}$}

To a solution of $4 \mathbf{b}(50.1 \mathrm{mg}, 0.102 \mathrm{mmol})$ in acetone $(15 \mathrm{~mL})$, solid $\left[\mathrm{H}_{3} \mathrm{O} \cdot 18\right.$-crown-6] [BF 4 ] was added (39.6 $\mathrm{mg}, 0.107 \mathrm{mmol}$ ). The solution was stirred to room temperature for $1 \mathrm{~h}$, then it was concentrated to a small volume, treated with ethyl ether and filtered off. Yield: $58 \%$. M.p. $(\mathrm{dec})=279$ ${ }^{\circ} \mathrm{C}$. Anal. Calc. for $\mathrm{C}_{14} \mathrm{H}_{18} \mathrm{BClF}_{4} \mathrm{~N}_{2} \mathrm{OPt}$ : C, $29.01 \%, \mathrm{H}, 3.13 \%, \mathrm{~N}, 4.83 \%$. Found: C, 29.37\%, H, 3.35\%, N, $4.68 \% .{ }^{1} \mathrm{H} \mathrm{NMR}\left(\mathrm{CDCl}_{3}\right): \delta=1.46\left(\mathrm{t}, 3 \mathrm{H}, \mathrm{J}_{\mathrm{H}-\mathrm{H}}=7.7 \mathrm{~Hz}, \mathrm{CH}_{3} \mathrm{Et}\right) ; 3.18\left(\mathrm{q}, 2 \mathrm{H}, \mathrm{J}_{\mathrm{H}-\mathrm{H}}=7.8 \mathrm{~Hz}, \mathrm{CH}_{2} \mathrm{Et}\right)$; 
3.69 (s with sat, $\left.6 \mathrm{H},{ }^{3} \mathrm{~J}_{\mathrm{Pt}-\mathrm{H}}=23 \mathrm{~Hz}, \mathrm{DMSO}\right) ; 7.49$ (d con sat, $1 \mathrm{H}, \mathrm{J}_{\mathrm{H}-\mathrm{H}}=8.4 \mathrm{~Hz},{ }^{3} \mathrm{~J}_{\mathrm{Pt}-\mathrm{H}}=\mathrm{nr}, \mathrm{H}_{5}$ ); 7.69 $\left(\mathrm{m}, 1 \mathrm{H}, \mathrm{J}_{\mathrm{H}-\mathrm{H}}=6.7 \mathrm{~Hz}, \mathrm{H}_{5^{\prime}}\right) ; 8.32\left(\mathrm{td}, 1 \mathrm{H}, \mathrm{J}_{\mathrm{H}-\mathrm{H}}=1.7,81 \mathrm{~Hz}, \mathrm{H}_{4^{\prime}}\right) ; 8.75\left(\mathrm{~d}, 1 \mathrm{H}, \mathrm{J}_{\mathrm{H}-\mathrm{H}}=8.1 \mathrm{~Hz}, \mathrm{H}_{3^{\prime}}\right) ; 9.37$ (d con sat, $\left.1 \mathrm{H}, \mathrm{J}_{\mathrm{H}-\mathrm{H}}=8.4 \mathrm{~Hz},{ }^{3} \mathrm{~J}_{\mathrm{Pt}-\mathrm{H}}=27 \mathrm{~Hz}, \mathrm{H}_{4}\right) ; 9.73$ (d with sat, $1 \mathrm{H}, \mathrm{J}_{\mathrm{H}-\mathrm{H}}=5.8 \mathrm{~Hz},{ }^{3} \mathrm{~J}_{\mathrm{Pt}-\mathrm{H}}=20.4 \mathrm{~Hz}$, $\left.\mathrm{H}_{6^{\prime}}\right) ; \delta=13.06(\mathrm{~s} \mathrm{br}, \mathrm{N}-\mathrm{H})$.

\section{8. $\left[\mathrm{Pt}\left(b p y^{6 E t}-\mathrm{H}\right)(\mathrm{Me})\left(\mathrm{PPh}_{3}\right)\right], \mathbf{6 b}$}

To a solution of $\mathbf{1 b}(50.0 \mathrm{mg}, 0.106 \mathrm{mmol})$ in acetone $(10 \mathrm{~mL})$, solid $\mathrm{PPh}_{3}$ was added $(29.7 \mathrm{mg}$, $0.113 \mathrm{mmol})$. The solution was stirred at room temperature for $1 \mathrm{~h}$, then it was concentrated to a small volume, treated with ethyl ether and filtered. Yield: $67 \%$. m.p. $=207.6{ }^{\circ} \mathrm{C}$. Anal. Calcd. for $\mathrm{C}_{31} \mathrm{H}_{29} \mathrm{~N}_{2}$ PPt: C, 56.79\%; H, 4.46\%; N, 4.27\%. Found, 56.92\%; H, 4.73\%; N, 4.01\%. ${ }^{1} \mathrm{H}$ NMR $\left(\mathrm{CDCl}_{3}\right)$ : $\delta=0.66\left(\mathrm{~d}\right.$ with sat, $\left.3 \mathrm{H},{ }^{3} \mathrm{~J}_{\mathrm{P}-\mathrm{H}}=7.8 \mathrm{~Hz},{ }^{2} \mathrm{~J}_{\mathrm{Pt}-\mathrm{H}}=84 \mathrm{~Hz}, \mathrm{Pt}_{-} \mathrm{CH}_{3}\right) ; 1.26\left(\mathrm{t}, 3 \mathrm{H}, \mathrm{J}_{\mathrm{H}-\mathrm{H}}=7.7 \mathrm{~Hz}, \mathrm{CH}_{3} \mathrm{Et}\right) ; 2.71$ $\left(\mathrm{q}, 2 \mathrm{H}, \mathrm{J}_{\mathrm{H}-\mathrm{H}}=7.7 \mathrm{~Hz}, \mathrm{CH}_{2} \mathrm{Et}\right) ; 6.56\left(\mathrm{~m}, 1 \mathrm{H}, \mathrm{J}_{\mathrm{H}-\mathrm{H}}=6.5 \mathrm{~Hz}, \mathrm{H}_{5^{\prime}}\right) ; 7.03$ (dd with sat, $1 \mathrm{H}, \mathrm{J}_{\mathrm{H}-\mathrm{H}}=7.7 \mathrm{~Hz}$, $\left.{ }^{4} \mathrm{JPt}_{\mathrm{Pt}}=15.7 \mathrm{~Hz}, \mathrm{H}_{5}\right) ; 7.37-7.22\left(\mathrm{~m}, \mathrm{H}\right.$ bpy $\left.+\mathrm{H} \mathrm{PPh}_{3}\right) ; 7.72-7.63\left(\mathrm{~m}, \mathrm{H} \mathrm{PPh}_{3}\right) ; 8.06$ (dd with sat, $1 \mathrm{H}$, $\left.{ }^{4} \mathrm{~J}_{\mathrm{P}-\mathrm{H}}=5.4 \mathrm{~Hz}, \mathrm{~J}_{\mathrm{H}-\mathrm{H}}=7.7 \mathrm{~Hz},{ }^{3} \mathrm{~J}_{\mathrm{Pt}-\mathrm{H}}=47 \mathrm{~Hz}, \mathrm{H}_{4}\right) ; 8.30\left(\mathrm{~d}, 1 \mathrm{H}, \mathrm{J}_{\mathrm{H}-\mathrm{H}}=7.8 \mathrm{~Hz}, \mathrm{H}_{3^{\prime}}\right) .{ }^{31} \mathrm{P} \mathrm{NMR}\left(\mathrm{CDCl}_{3}\right)$ : $\delta=32.7$ (s with sat, $1 \mathrm{P}, \mathrm{J}_{\mathrm{Pt}-\mathrm{P}}=2221.1 \mathrm{~Hz}, \mathrm{Pt}-\mathrm{P}$ ).

\section{9. $\left.\mathrm{Pt}\left(\mathrm{bpy} \mathrm{y}^{6 \mathrm{OMe}}-\mathrm{H}\right)(\mathrm{Cl})\left(\mathrm{PPh}_{3}\right)\right], 7 \mathbf{a}$}

To a solution of $4 \mathbf{a}(100.8 \mathrm{mg}, 0.2041 \mathrm{mmol})$ in acetone $(15 \mathrm{~mL})$, solid $\mathrm{PPh}_{3}$ was added $(55.1 \mathrm{mg}$, $0.210 \mathrm{mmol}$ ). The solution was stirred at room temperature for $1 \mathrm{~h}$, then it was concentrated to small volume, treated with ethyl ether and filtered. Yield: $67 \%$. M.p. $=286{ }^{\circ} \mathrm{C}$. Anal. Calc. for $\mathrm{C}_{29} \mathrm{H}_{24} \mathrm{~N}_{2} \mathrm{ClOPPt}: \mathrm{C}, 51.38 \%, \mathrm{H}, 3.57 \%$, N, $4.13 \%$. Found: $51.56 \%, \mathrm{H}, 3.43 \%, \mathrm{~N}, 4.30 \%$. ${ }^{1} \mathrm{H}$ NMR $\left(\mathrm{CDCl}_{3}\right): \delta=3.91\left(\mathrm{~s}, 3 \mathrm{H}, \mathrm{OCH}_{3}\right) ; 5.99$ (d with sat, $\left.1 \mathrm{H}, \mathrm{J}_{\mathrm{H}-\mathrm{H}}=8.5 \mathrm{~Hz},{ }^{4} \mathrm{~J}_{\mathrm{Pt}-\mathrm{H}}=\mathrm{ca} 10 \mathrm{~Hz}, \mathrm{H}_{5}\right) ; 6.72(\mathrm{dd}$, $\left.1 \mathrm{H},{ }^{4} \mathrm{~J}_{\mathrm{P}-\mathrm{H}}=2.7 \mathrm{~Hz}, \mathrm{~J}_{\mathrm{H}-\mathrm{H}}=8.5 \mathrm{~Hz},{ }^{3} \mathrm{~J}_{\mathrm{Pt}-\mathrm{H}}=46 \mathrm{~Hz}, \mathrm{H}_{4}\right) ; 7.34-7.48\left(\mathrm{~m}, 10 \mathrm{H}, \mathrm{H}_{5^{\prime}}+\mathrm{H}_{\mathrm{o}+\mathrm{p}} \mathrm{PPh}_{3}\right) ; 7.75-7.83$ $\left(\mathrm{m}, 6 \mathrm{H}, \mathrm{H}_{\mathrm{m}} \mathrm{PPh}_{3}\right) ; 7.93\left(\mathrm{td}, 1 \mathrm{H}, \mathrm{J}_{\mathrm{H}-\mathrm{H}}=1.5 \mathrm{~Hz}, \mathrm{~J}_{\mathrm{H}-\mathrm{H}}=7.8 \mathrm{~Hz}, \mathrm{H}_{4^{\prime}}\right) ; 8.18\left(\mathrm{~d}, 1 \mathrm{H}, \mathrm{J}_{\mathrm{H}-\mathrm{H}}=7.9 \mathrm{~Hz}, \mathrm{H}_{3^{\prime}}\right)$; 9.79 (broad m with sat, $1 \mathrm{H},{ }^{4} \mathrm{~J}_{\mathrm{P}-\mathrm{H}}=$ ca $5 \mathrm{~Hz}, \mathrm{~J}_{\mathrm{H}-\mathrm{H}}=$ ca $5 \mathrm{~Hz},{ }^{3} \mathrm{~J}_{\mathrm{Pt}-\mathrm{H}}=$ ca $\left.28 \mathrm{~Hz}, \mathrm{H}_{6^{\prime}}\right) .{ }^{31} \mathrm{P} \mathrm{NMR}\left(\mathrm{CDCl}_{3}\right)$ $\delta=22.31$ (s with sat, $\mathrm{J}_{\mathrm{Pt}-\mathrm{P}}=4245 \mathrm{~Hz}, \mathrm{PPh}_{3}$ ).

\subsection{0. [.Pt $\left.\left(b p y^{6 E t}-H\right)(C l)\left(P P h_{3}\right)\right], 7 \mathbf{b}$}

Complex $7 \mathbf{b}$ was obtained as complex $7 \mathbf{a}$ using $4 \mathbf{b}$ in place of $4 \mathbf{a}$. Yield: $80 \%$. M.p. $=271{ }^{\circ} \mathrm{C}$. Anal. Calcd. for $\mathrm{C}_{30} \mathrm{H}_{26} \mathrm{ClN}_{2}$ PPt: C, $53.30 \%$; H, 3.88\%; N, 4.14\%. Found C, $52.98 \% ; \mathrm{H}, 3.45 \%$; N, $4.21 \%$.

${ }^{1} \mathrm{H} \mathrm{NMR}\left(\mathrm{CDCl}_{3}\right): \delta=1.24\left(\mathrm{t}, 2 \mathrm{H}, \mathrm{J}_{\mathrm{H}-\mathrm{H}}=7.7 \mathrm{~Hz}, \mathrm{CH}_{3} \mathrm{Et}\right) ; 2.61\left(\mathrm{q}, 3 \mathrm{H}, \mathrm{J}_{\mathrm{H}-\mathrm{H}}=7.7 \mathrm{~Hz}, \mathrm{CH}_{2} \mathrm{Et}\right) ; 6.30$ (d with broad sat, $1 \mathrm{H}, \mathrm{J}_{\mathrm{H}-\mathrm{H}}=8.1 \mathrm{~Hz},{ }^{4} \mathrm{~J}_{\mathrm{Pt}-\mathrm{H}}$ not resolved, $\left.\mathrm{H}_{5}\right) ; 6.75\left(\mathrm{dd}, 1 \mathrm{H}, \mathrm{J}_{\mathrm{H}-\mathrm{H}}=8.1 \mathrm{~Hz},{ }^{4} \mathrm{~J}_{\mathrm{P}-\mathrm{H}}=2.8 \mathrm{~Hz}\right.$, ${ }^{3} \mathrm{JPt}_{\mathrm{Pt}}=$ ca $\left.49 \mathrm{~Hz}, \mathrm{H}_{4}\right) ; 7.34-7.47\left(\mathrm{~m}, 10 \mathrm{H}, \mathrm{H}\right.$ bpy $\left.+\mathrm{PPh}_{3}\right) ; 7.77-7.84(\mathrm{~m}, 6 \mathrm{H}, \mathrm{H} \mathrm{PPh}), 7.94\left(\mathrm{t}, 1 \mathrm{H}, \mathrm{J}_{\mathrm{H}-\mathrm{H}}=\right.$ $\left.7.2 \mathrm{~Hz}, \mathrm{H}_{4^{\prime}}\right) ; 8.31\left(\mathrm{~d}, 1 \mathrm{H}, \mathrm{J}_{\mathrm{H}-\mathrm{H}}=8.1 \mathrm{~Hz}, \mathrm{H}_{3^{\prime}}\right) ; 9.82\left(\mathrm{~m}\right.$ with sat, $\left.1 \mathrm{H},{ }^{3} \mathrm{~J}_{\mathrm{Pt}-\mathrm{H}}=\mathrm{ca} 28 \mathrm{~Hz}, \mathrm{H}_{6^{\prime}}\right) .{ }^{31} \mathrm{P} \mathrm{NMR}$ $\left(\mathrm{CDCl}_{3}\right) \delta=22.61$ (s with sat, $\left.\mathrm{JPt}_{\mathrm{P}}=4297 \mathrm{~Hz}, \mathrm{PPh}_{3}\right)$.

\subsection{1. [.Pt $\left.\left(\kappa^{2}-\mathrm{N}, \mathrm{N}-b p y^{6 \mathrm{OMe}}\right)(\mathrm{Me})\left(\mathrm{PPh}_{3}\right)\right]\left[B F_{4}\right], 8 \mathbf{a}-B F_{4}$}

(a) To a solution of $6 \mathbf{a}(98.0 \mathrm{mg}, 0.149 \mathrm{mmol})$ in acetone $(20 \mathrm{~mL})$, solid $\left[\mathrm{H}_{3} \mathrm{O} \cdot 18\right.$-crown-6] [ $\left.\mathrm{BF}_{4}\right]$ was added $(59.0 \mathrm{mg}, 0.159 \mathrm{mmol})$. The solution was stirred for $30^{\prime}$, then it was treated with diethyl ether and filtered. Yield 85\%. Anal. Calcd. for $\mathrm{C}_{30} \mathrm{H}_{28} \mathrm{BF}_{4} \mathrm{~N}_{2} \mathrm{OPPt}$ C, $48.34 \% ; \mathrm{H}, 3.79 \%$; $\mathrm{N}, 3.76 \%$. Found C, $47.98 \% ; \mathrm{H}, 3.54 \%$; N, $4.01 \%$.

(b) To a solution of $6 \mathrm{a}(10.0 \mathrm{mg}, 0.0152 \mathrm{mmol})$ in deuterated chloroform $(2 \mathrm{~mL})\left[\mathrm{H}_{3} \mathrm{O} \cdot 18\right.$-crown-6][ $\left.\mathrm{BF}_{4}\right]$ was added $(6.5 \mathrm{mg}, 0.017 \mathrm{mmol})$. The resulting dark yellow solution was put in an NMR tube and the reaction was followed by means of ${ }^{1} \mathrm{H},{ }^{31} \mathrm{P},{ }^{1} \mathrm{H}$ COSY and ${ }^{1} \mathrm{H}$ NOESY spectra.

${ }^{1} \mathrm{H}$ NMR $\left(\mathrm{CDCl}_{3}\right) \delta=0.64$ (d with sat, $\left.1 \mathrm{H},{ }^{3} \mathrm{~J}_{\mathrm{P}-\mathrm{H}}=3.6 \mathrm{~Hz},{ }^{2} \mathrm{~J}_{\mathrm{Pt}-\mathrm{H}}=74.0 \mathrm{~Hz}, \mathrm{Pt}-\mathrm{CH}_{3}\right) ; 2.61(\mathrm{~s}, 3 \mathrm{H}$, $\left.\mathrm{O}-\mathrm{CH}_{3}\right) ; 6.79\left(\mathrm{~d}, 1 \mathrm{H}, \mathrm{J}_{\mathrm{H}-\mathrm{H}}=8.4 \mathrm{~Hz}, \mathrm{H}_{5}\right) ; 7.45-7.38\left(\mathrm{~m}, 6 \mathrm{H}, \mathrm{H}^{\text {meta }} \mathrm{PPh}_{3}\right) ; 7.53-7.46\left(\mathrm{~m}, 3 \mathrm{H}, \mathrm{H}^{\text {para }} \mathrm{PPh}_{3}\right)$; $7.72\left(\mathrm{~m}, 1 \mathrm{H}, \mathrm{H}_{5^{\prime}}\right) ; 7.81-7.74\left(\mathrm{~m}, 6 \mathrm{H}, \mathrm{H}^{\text {orto }} \mathrm{PPh}_{3}\right) ; 8.24\left(\mathrm{t}, 1 \mathrm{H}, \mathrm{J}_{\mathrm{H}-\mathrm{H}}=8.0 \mathrm{~Hz}, \mathrm{H}_{4}\right) ; 8.32\left(\mathrm{~d}, 1 \mathrm{H}, \mathrm{J}_{\mathrm{H}-\mathrm{H}}=\right.$ $\left.8.0 \mathrm{~Hz}, \mathrm{H}_{3}\right) ; 8.39\left(\mathrm{t}, 1 \mathrm{H}, \mathrm{J}_{\mathrm{H}-\mathrm{H}}=7.9 \mathrm{~Hz}, \mathrm{H}_{4^{\prime}}\right) ; 8.73\left(\mathrm{~d}, 1 \mathrm{H}, \mathrm{J}_{\mathrm{H}-\mathrm{H}}=8.3 \mathrm{~Hz}, \mathrm{H}_{5}\right) ; 8.86$ (broad m with sat, $1 \mathrm{H}$, $\left.{ }^{3} \mathrm{~J}_{\mathrm{Pt}-\mathrm{H}}=34 \mathrm{~Hz}, \mathrm{H}_{6^{\prime}}\right) .{ }^{31} \mathrm{P} \mathrm{NMR}\left(\mathrm{CDCl}_{3}\right) \delta=17.40 \mathrm{ppm}$ (s with sat, $\left.\mathrm{J}_{\mathrm{Pt}-\mathrm{P}}=4510 \mathrm{~Hz}\right)$. 
${ }^{13} \mathrm{C} \mathrm{NMR}\left(\mathrm{CDCl}_{3}\right): \delta=-13.14$ (d with sat, $\left.\mathrm{JPt}_{\mathrm{Pt}}=723 \mathrm{~Hz},{ }^{2} \mathrm{~J}_{\mathrm{P}-\mathrm{C}}=5.1 \mathrm{~Hz}, \mathrm{Pt}-\mathrm{CH}_{3}\right) ; 52.95\left(\mathrm{~s}, \mathrm{OCH}_{3}\right)$; 111.60 (d with sat, J = 5.6, $56.1 \mathrm{~Hz}$ ); 123.25 (s with sat); 128.26 (d); 130.19 (d); 132.36 (d with sat); 135.04 (d with sat); 137.33 (s); 143.08 (s with sat); 149.85 (s, Cq); 150. 41 (d with sat); 151.06 (s, Cq); 161.67 (s, Cq); 162.22 (s with sat, Cq); 164.96 (d with sat, Cq).

\subsection{2. [.Pt $\left.\left(\mathrm{bpy}^{6 E t *}\right)(\mathrm{Me})\left(\mathrm{PPh}_{3}\right)\right]\left[B \mathrm{BF}_{4}\right], \mathbf{9 b}-\mathrm{BF}_{4}$}

To a solution of $\mathbf{6 b}(30.0 \mathrm{mg}, 0.0458 \mathrm{mmol})$ in acetone $(15 \mathrm{~mL})$, solid $\left[\mathrm{H}_{3} \mathrm{O} \cdot 18\right.$-crown-6] $\left[\mathrm{BF}_{4}\right]$ was added $(17.2 \mathrm{mg}, 0.0465 \mathrm{mmol})$. The solution was stirred at room temperature for $1 \mathrm{~h}$, then it was concentrated to small volume, treated with diethyl ether and filtered. Yield: $64 \%$. M.p. $=123{ }^{\circ} \mathrm{C}$.

Anal. Calcd. for $\mathrm{C}_{31} \mathrm{H}_{30} \mathrm{BF}_{4} \mathrm{~N}_{2} \mathrm{PPt}$ : C, $50.08 \% ; \mathrm{H}, 4.07 \% ; \mathrm{N}, 3.77 \%$. Found C, $49.92 \% ; \mathrm{H}, 3.95 \%$; $\mathrm{N}, 3.54 \% .{ }^{1} \mathrm{H}$ NMR $\left(\mathrm{CDCl}_{3}\right) \delta=0.80$ (d with sat, $\left.3 \mathrm{H}, \mathrm{J}_{\mathrm{H}-\mathrm{H}}=7.3 \mathrm{~Hz},{ }^{2} \mathrm{~J}_{\mathrm{Pt}-\mathrm{H}}=82.5 \mathrm{~Hz}, \mathrm{Pt}_{-} \mathrm{CH}_{3}\right) ; 1.46$ $\left(\mathrm{t}, 3 \mathrm{H}, \mathrm{J}_{\mathrm{H}-\mathrm{H}}=7.6 \mathrm{~Hz}, \mathrm{CH}_{3} \mathrm{Et}\right) ; 3.18\left(\mathrm{q}, 2 \mathrm{H}, \mathrm{J}_{\mathrm{H}-\mathrm{H}}=7.6 \mathrm{~Hz}, \mathrm{CH}_{2} \mathrm{Et}\right) ; 6.90\left(\mathrm{~m}, 1 \mathrm{H}, \mathrm{J}_{\mathrm{H}-\mathrm{H}}=6.6 \mathrm{~Hz}, \mathrm{H}_{5^{\prime}}\right)$; 7.52-7.41 (m, 10H, H PPh 3 ); 7.56 ppm (d with sat, $1 \mathrm{H}, \mathrm{J}_{\mathrm{H}-\mathrm{H}}=7.7 \mathrm{~Hz},{ }^{4} \mathrm{~J}_{\mathrm{Pt}-\mathrm{H}}=$ ca $\left.14 \mathrm{~Hz}, \mathrm{H}_{5}\right) ; 7.75-7.86$ $\left(\mathrm{m}, 5 \mathrm{H}, \mathrm{H} \mathrm{PPh}\right.$ ) $; 7.85$ (d with sat, $\left.1 \mathrm{H}, \mathrm{J}_{\mathrm{H}-\mathrm{H}}=5.8 \mathrm{~Hz},{ }^{3} \mathrm{~J}_{\mathrm{Pt}-\mathrm{H}}=13 \mathrm{~Hz}, \mathrm{H}_{6^{\prime}}\right) ; 8.10\left(\mathrm{t}, 1 \mathrm{H}, \mathrm{J}_{\mathrm{H}-\mathrm{H}}=8.0 \mathrm{~Hz}\right.$, $\left.\mathrm{H}_{4^{\prime}}\right) ; 8.69\left(\mathrm{~d}, 1 \mathrm{H}, \mathrm{J}_{\mathrm{H}-\mathrm{H}}=8.2 \mathrm{~Hz}, \mathrm{H}_{3^{\prime}}\right) ; 8.85$ (dd with sat, $1 \mathrm{H},{ }^{4} \mathrm{~J}_{\mathrm{P}-\mathrm{H}}=5.2 \mathrm{~Hz}, \mathrm{~J}_{\mathrm{H}-\mathrm{H}}=7.8 \mathrm{~Hz},{ }^{3} \mathrm{~J}_{\mathrm{Pt}-\mathrm{H}}=51 \mathrm{~Hz}$, $\left.\mathrm{H}_{4}\right) ; 13.2$ (s br, N-H). ${ }^{31} \mathrm{P}$ NMR $\left(\mathrm{CDCl}_{3}\right): \delta=31.2$ (s with sat, $1 \mathrm{P}, \mathrm{J}_{\mathrm{Pt}-\mathrm{P}}=2400 \mathrm{~Hz}, \mathrm{Pt}-\mathrm{P}$ ).

\subsection{3. $\left[P t\left(b p y^{6 E t *}\right)(C l)\left(P P h_{3}\right)\right]\left[B F_{4}\right], \mathbf{1 0 b}-B F_{4}$}

To a solution of $7 \mathbf{b}(30.3 \mathrm{mg}, 0.0448 \mathrm{mmol})$ in acetone $(15 \mathrm{~mL})$, solid $\left[\mathrm{H}_{3} \mathrm{O} \cdot 18\right.$-crown-6] $\left[\mathrm{BF}_{4}\right]$ was added $(17.2 \mathrm{mg}, 0.0465 \mathrm{mmol})$. The solution was stirred to room temperature for $1 \mathrm{~h}$, then it was concentrated to small volume, treated with diethyl ether and filtered. Yield: $89 \%$. M.p. $(\mathrm{dec})=243{ }^{\circ} \mathrm{C}$. Anal. Calcd. for $\mathrm{C}_{30} \mathrm{H}_{27} \mathrm{BClF}_{4} \mathrm{~N}_{2}$ PPt: C, $47.17 \% ; \mathrm{H}, 3.56 \%$; N 3.67\%. Found, $47.33 \% ; \mathrm{H}, 3.79 \%$; , $3.46 \% .{ }^{1} \mathrm{H}$ NMR $\left(\mathrm{CDCl}_{3}\right): \delta=1.35\left(\mathrm{t}, 3 \mathrm{H}, \mathrm{J}_{\mathrm{H}-\mathrm{H}}=7.7 \mathrm{~Hz}, \mathrm{CH}_{3} \mathrm{Et}\right) ; 3.06\left(\mathrm{q}, 2 \mathrm{H}, \mathrm{J}_{\mathrm{H}-\mathrm{H}}=7.7 \mathrm{~Hz}, \mathrm{CH}_{2} \mathrm{Et}\right)$; $6.79\left(\mathrm{~d}, 1 \mathrm{H}, \mathrm{J}_{\mathrm{H}-\mathrm{H}}=8.3 \mathrm{~Hz}, \mathrm{H}_{5}\right) ; 6.79\left(\mathrm{~d}, 1 \mathrm{H}, \mathrm{J}_{\mathrm{H}-\mathrm{H}}=8.3 \mathrm{~Hz}, \mathrm{H}_{5}\right) ; 7.56-7.49\left(\mathrm{~m}, 2 \mathrm{H}, \mathrm{H}_{5^{\prime}}\right.$ and $\left.\mathrm{an}_{4}\right) ; 7.81-7.69$ $\left(\mathrm{m}, \mathrm{H} \mathrm{PPh}_{3}\right) ; 8.32\left(\mathrm{t}, 1 \mathrm{H}, \mathrm{J}_{\mathrm{H}-\mathrm{H}}=7.8 \mathrm{~Hz}, \mathrm{H}_{4^{\prime}}\right) ; 8.80\left(\mathrm{~d}, 1 \mathrm{H}, \mathrm{J}_{\mathrm{H}-\mathrm{H}}=7.8 \mathrm{~Hz}, \mathrm{H}_{3^{\prime}}\right) ; 10.0\left(\mathrm{~m}\right.$ with sat, $1 \mathrm{H},{ }^{3} \mathrm{JPt}_{\mathrm{Pt}-\mathrm{H}}$ $\left.=30.2 \mathrm{~Hz}, \mathrm{H}_{6^{\prime}}\right) ; 13.3(\mathrm{~s} \mathrm{br}, \mathrm{N}-\mathrm{H}) .{ }^{31} \mathrm{P}$ NMR $\left(\mathrm{CDCl}_{3}\right): \delta=19.59$ (s with sat, $\left.1 \mathrm{P}, \mathrm{JPt}_{\mathrm{Pt}} \mathrm{P}=4139 \mathrm{~Hz}, \mathrm{Pt}-\mathrm{P}\right)$.

\subsection{Reaction between 1a, $\left[\mathrm{Pt}\left(b p y^{6 \mathrm{OMe}}-\mathrm{H}\right)(\mathrm{Me}) \mathrm{DMSO}\right]$, and [ $\mathrm{H}_{3} \mathrm{O} \cdot 18$-crown-6][BF 4$]$}

The reaction between $1 \mathrm{a}$ and $\left[\mathrm{H}_{3} \mathrm{O} \cdot 18\right.$-crown-6] $\left[\mathrm{BF}_{4}\right]$ was performed under the same conditions of the analogous reaction of complex $\mathbf{1 b}$. The reaction was also followed by means of ${ }^{1} \mathrm{H}$ NMR. Despite several attempts, we were not able to identify the reaction products, with the exception of a singlet at $0.17 \mathrm{ppm}$ (acetone $d_{6}$ ), attributed to free methane.

\section{Results}

\subsection{Stereoelectronic Properties of Substituted 2,2'-bipyridines}

The coordinative behavior of substituted bipyridines is strictly dependent on the electronic and steric properties given by their substituents. In the particular case of rollover cyclometallation, two points should be considered: coordination/decoordination of the labile nitrogen donor atom, and activation of a remote $\mathrm{C}-\mathrm{H}$ bond.

It is generally agreed that after chelation, the first step of the process is nitrogen detachment (see Scheme 1), therefore a weaker M-N bond will facilitate the rollover reaction; in contrast, good donor nitrogen atoms will stabilize chelated adducts and contrast rollover metalation. A weak M-N bond can be achieved electronically, by reducing the electron density at the nitrogen (e.g., introducing an electron-withdrawing substituent in the ring), or sterically, employing a bulky substituent in proximity of the nitrogen atom [8].

The last step of the process, i.e., the remote $\mathrm{C}-\mathrm{H}$ bond activation (see Scheme 1, from D to E), in the case of platinum (II) likely involves a nucleophilic behavior of the metal [7,8]; in this case, electron withdrawing groups are expected to facilitate the process. 
Owing to these considerations, the $\mathrm{CF}_{3}$ substituent in 6- $\mathrm{CF}_{3}-2,2^{\prime}$-bipyridine (bpy ${ }^{6 \mathrm{CF} 3}$ ) favors all of these steps, decreasing the electronic density of the nearby nitrogen, increasing the steric congestion around it and activating the $\mathrm{C}(3)-\mathrm{H}$ bond towards nucleophilic attack of the metal. As a consequence, rollover cyclometalation of bpy ${ }^{6 \mathrm{CF} 3}$ is very fast even at room temperature [67]. It is also worth noting that starting from electron-rich $\mathrm{Pt}(\mathrm{II})$ complexes, such as $\left[\mathrm{PtMe}_{2}(\mathrm{DMSO})_{2}\right]$, the process is irreversible due to methane formation, so kinetic factors will rule the reaction outcome.

We report here our investigation on two 6-substituted-2,2'-bipyridines $\left(\mathrm{bpy}^{6 \mathrm{R}}\right)$ : 6-ethyl-2,2'-bipyridine (bpy ${ }^{6 \mathrm{Et}}, \mathrm{R}=\mathrm{CH}_{2} \mathrm{CH}_{3}$ ) and 6-methoxy-2,2'-bipyridine (bpy ${ }^{6 \mathrm{OMe}}, \mathrm{R}=\mathrm{OCH}_{3}$ ), in comparison with previously studied 2,2'-bipyridine (bpy, $\mathrm{R}=\mathrm{H}), 6$-methyl-2,2'-bipyridine (bpy ${ }^{6 \mathrm{Me}}$, $\mathrm{R}=\mathrm{CH}_{3}$ ), and 6-trifluoromethyl-2,2'-bipyridine (bpy $\left.{ }^{6 \mathrm{CF} 3}, \mathrm{R}=\mathrm{CF}_{3}\right)$ [67].

Evaluation of the donor capabilities of the nitrogen atoms in 2,2'-bipyridines may be extrapolated by analyzing proton affinity and basicity data of the corresponding substituted pyridines and pyridinium ions (see Table 1).

Table 1. Stereoelectronic properties of substituted pyridines and 2,2'-bipyridines.

\begin{tabular}{|c|c|c|c|c|}
\hline $\mathbf{R}^{\mathbf{a}}$ & Proton Affinity ${ }^{69}$ & Basicity ${ }^{69}$ & pKa Pyridinium $^{70}$ & $\zeta$ Angle $\left({ }^{\circ}\right)$ \\
\hline $\mathrm{H}$ & 922.2 & 889.5 & 5.17 & 98.8 \\
\hline $2-\mathrm{CH}_{3}\left(6-\mathrm{CH}_{3}\right)$ & 936.0 & 903.3 & 5.97 & 125.1 \\
\hline $3-\mathrm{CH}_{3}\left(5-\mathrm{CH}_{3}\right)$ & 932.2 & 899.6 & 5.68 & \\
\hline $4-\mathrm{CH}_{3}$ & 936.0 & 903.3 & 6.02 & \\
\hline $2-\mathrm{C}_{2} \mathrm{H}_{5}\left(6-\mathrm{C}_{2} \mathrm{H}_{5}\right)$ & 941.0 & 908.3 & 5.97 & $157.1(\max ), 125.1(\min )$ \\
\hline $3-\mathrm{C}_{2} \mathrm{H}_{5}\left(6-\mathrm{C}_{2} \mathrm{H}_{5}\right)$ & 936.8 & 904.2 & 5.70 & \\
\hline $4-\mathrm{C}_{2} \mathrm{H}_{5}$ & 939.7 & 907.1 & 6.02 & \\
\hline $2-\mathrm{CF}_{3}\left(6-\mathrm{CF}_{3}\right)$ & 885.3 & 852.7 & - & 137.6 \\
\hline $3-\mathrm{CF}_{3}\left(6-\mathrm{CF}_{3}\right)$ & 890.4 & 857.7 & $3.36^{71}$ & \\
\hline $4-\mathrm{CF}_{3}$ & 891.6 & 859.0 & $3.59^{71}$ & \\
\hline $2-\mathrm{OCH}_{3}\left(6-\mathrm{OCH}_{3}\right)$ & 925.9 & 893.3 & 3.28 & $152.3(\max ), 109.3(\min )$ \\
\hline $3-\mathrm{OCH}_{3}\left(6-\mathrm{OCH}_{3}\right)$ & 930.9 & 898.3 & 4.88 & \\
\hline $4-\mathrm{OCH}_{3}$ & 948.9 & 916.3 & 6.62 & \\
\hline
\end{tabular}

Data reported in Table 1 confirms that methyl and ethyl substituents have a marked electron-donor effect in all positions, although to a smaller extent in position 3 , while the opposite is true for $\mathrm{CF}_{3}$. In contrast, the methoxy substituent is not so straightforward in its contribution, having inductive electron withdrawing effect ( $-\mathrm{I}$ effect) but mesomeric electron donating effect (+M effect) [71]. In the gas phase, proton affinity of methoxypyridines is only slightly higher than that of pyridine, but in solution the pKa values show that 2-methoxy-pyridine is a worse donor with respect to pyridine by two pKa units (pKa $=3.1-3.2$ vs. 5.2), likely due to solvation effects.

In contrast, the pKa value of 4-methoxy-pyridinium ion (6.62) shows that a methoxy substituent in the para position makes the nitrogen a better $\sigma$-donor. This value suggests that for a MeO-group in the para position, the mesomeric effect is predominant (the nitrogen is more basic and electron-rich than that in 4-Me-pyridine). By extrapolation, a para C-H bond will have a higher electron density and will be less prone to electrophilic activation.

A second important element in rollover metalation is given by steric factors, which play a significant role in the regioselectivity of the process. It should be noted that in 6-substituted bipyridines, only the substituted pyridine ring undergoes $\mathrm{C}-\mathrm{H}$ activation, both with $6-\mathrm{CH}_{3}$ and with $6-\mathrm{CF}_{3}$ substituents. Only in 5-substitued 2,2'-bipyridines a different behavior of the substituted and unsubstituted ring has been reported [51].

Previous data show an acceleration of the process due to the bulkiness of the substituent (e.g., 6-tert-butyl-2,2'-bipyridine vs. 6-Me-bipyridine [51]). With the intention to measure the steric 
contribution to the reaction, we have recently reported the $\zeta$ angle of substituted bipyridines [51], which evaluated the steric hindrance of a bipyridine ligand.

The angle $\zeta$ is defined as the angle between the bisector of the $\mathrm{N}-\mathrm{Pt}-\mathrm{N}$ angle and the tangent to the remotest van der Waals surface of the substituent, passing through the metal center, as depicted in Figure 2 for $\left[\mathrm{Pt}\left(\mathrm{bpy}^{6 \mathrm{Me}}\right)\left(\mathrm{CH}_{3}\right)_{2}\right]$.

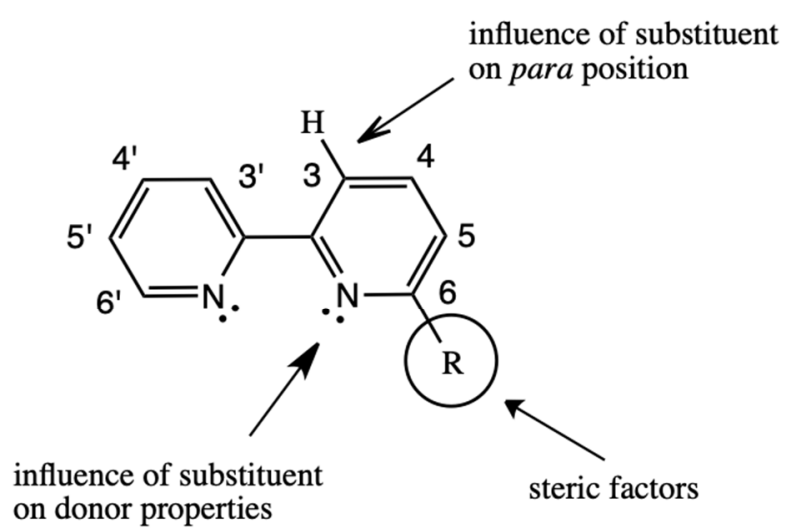

A

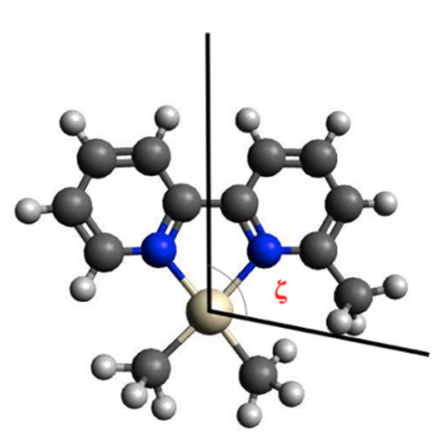

B

Figure 2. (A) Stereoelectronic factors and numbering scheme in 6-substituted 2,2'-bipyridines (6-R-2,2'-bipiridine, bpy ${ }^{6 \mathrm{R}}: \mathrm{R}=\mathrm{H}, \mathrm{CH}_{3}, \mathrm{OCH}_{3}, \mathrm{CH}_{2} \mathrm{CH}_{3}, \mathrm{~F}, \mathrm{CF}_{3}, \mathrm{Ph}, \mathrm{CR}_{2} \mathrm{Ph}$, etc.); (B) $\zeta$ angle for $\left[\mathrm{Pt}\left(\mathrm{bpy}{ }^{6 \mathrm{Me}}\right)\left(\mathrm{CH}_{3}\right)_{2}\right]$.

These data show that unsubstituted 2,2'-bipyridine occupies only $8.8^{\circ}$ above the theoretical $90^{\circ}$ available for a square planar configuration. A methyl substituent in position 6 , with a $\zeta$ angle of ca $125^{\circ}$ exceeds the available space by $35^{\circ}$. For the two ligands compared in this paper, bpy ${ }^{6 \mathrm{Et}}$ and bpy ${ }^{6 \mathrm{OMe}}$, it is possible to identify a minimum and a maximum angle due to substituent flexibility, whereas the maximum is similar for both the ligands $\left(157^{\circ}\right.$ vs. $152^{\circ}$, respectively) and the minimum hindrance of bpy ${ }^{6 \mathrm{OMe}}$ is definitely smaller $\left(109^{\circ}\right.$ vs. $\left.125^{\circ}\right)$.

Putting together all these data, it is expected that, in comparison with the unsubstituted 2,2'-bipyridine, 6-ethyl-2,2'-bipyridine, bpy ${ }^{6 \mathrm{Et}}$ possesses a better nitrogen donor in the substituted ring, whereas bpy ${ }^{6 \mathrm{OMe}}$ has a less basic one. Both the substituted ligands are expected to have a favorable detachment of the second nitrogen (first act of the rollover process: from A to B in Scheme 1) for steric reasons (bpy ${ }^{6 \mathrm{Et}}$ favored in respect to bpy ${ }^{6 \mathrm{OMe}}$ ) whereas bpy ${ }^{6 \mathrm{OMe}}$ will decoordinate easily the nitrogen donor due to its electronic properties.

As for the remote C-H bond activation, (Scheme 1, from B to C) bpy ${ }^{6 \mathrm{Et}}$ will be favored, with the ethyl substituent being a worst electron-donor in the para position than the methoxy one.

Putting together all these data it may be expected that bpy ${ }^{6 \mathrm{Et}}$ and bpy ${ }^{6 \mathrm{OMe}}$ may possess a similar steric hindrance but clearly different electronic properties.

Furthermore, it is worth reminding that the nature of the substituent will also have influence on the reactivity of corresponding rollover species, and the investigation of this effect is the second scope of this research work.

\subsection{Synthesis and Characterization}

In our experience, the best starting complex for $\mathrm{Pt}(\mathrm{II})$ rollover cyclometallation is the electron-rich derivative $\left[\mathrm{PtMe}_{2}(\mathrm{DMSO})_{2}\right]$. With this starting complex, the reaction proceeds even at room temperature for both ligands studied in this paper. In order to obtain reasonable conversions, the syntheses may be optimized operating in acetone at $40-50^{\circ} \mathrm{C}$ to give the rollover complexes [ $\left.\mathrm{Pt}\left(\mathrm{bpy}^{6 \mathrm{OMe}}-\mathrm{H}\right)(\mathrm{Me})(\mathrm{DMSO})\right]$, 1a, and $\left(\left[\mathrm{Pt}\left(\mathrm{bpy}^{6 \mathrm{Et}}-\mathrm{H}\right)(\mathrm{Me})(\mathrm{DMSO})\right], \mathbf{1 b}\right.$.

Activation of bpy ${ }^{6 \mathrm{OMe}}$ has been recently reported by some of us [66] and occurs easily, whereas activation of $\mathrm{bpy}^{6 \mathrm{Et}}$ proceeds slowly at room temperature. Bpy ${ }^{6 \mathrm{Et}}$ has a slightly greater 
steric hindrance than bpy ${ }^{6 \mathrm{OMe}}$, hence the easier $\mathrm{C}-\mathrm{H}$ bond activation in bpy ${ }^{6 \mathrm{OMe}}$ should not be ascribed to steric factors but may be due to the scarce donor ability of the nitrogen atom close to the OMe substituent.

The rollover metalation is clearly confirmed, in the ${ }^{1} \mathrm{H}$ NMR spectrum, by (i) the absence of the $\mathrm{H}_{3}$ proton; (ii) the $\mathrm{AB}$ system with satellites given by the remaining $\mathrm{H} 4$ and $\mathrm{H} 5$ protons in the substituted pyridine ring; (iii) coordination of the Me and DMSO ligands (confirmed by ${ }^{195} \mathrm{Pt}$ satellites), (iv) coordination shift and ${ }^{195} \mathrm{Pt}$ satellites of the $\mathrm{H6}^{\prime}$ proton.

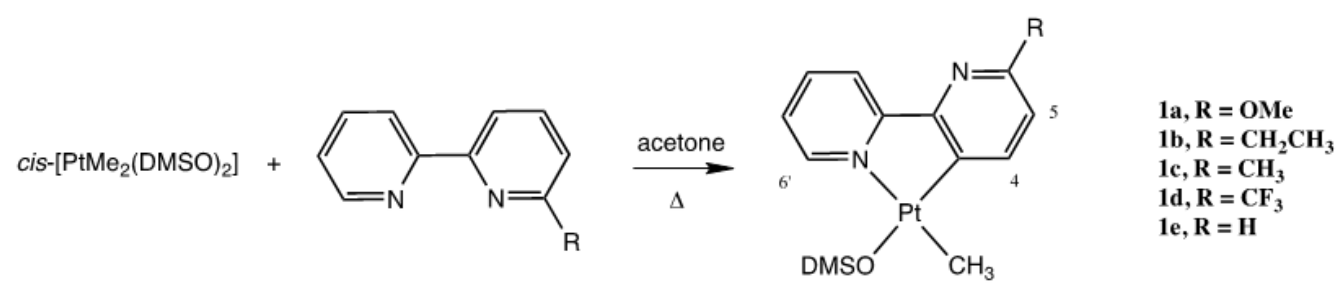

Synthesis of complexes 1a-e

In order to evaluate differences in the properties of rollover complexes due to the substituent, we compared the NMR data of a series of substituted 2,2'-bipyridines obtained in our laboratory (6-R-2,2'-bpy, $\mathrm{R}=\mathrm{OMe}, \mathrm{Et}, \mathrm{Me}, \mathrm{CH}_{3}, \mathrm{CF}_{3}, \mathrm{Ph}, \mathrm{H}$ ). Comparison of ${ }^{1} \mathrm{H} \mathrm{NMR}$ data of complexes 1a-1e (Table 2) shows, in general, minor differences. An interesting trend is displayed by the $\mathrm{H}_{4}$ proton, whose coupling constant with ${ }^{195} \mathrm{Pt}\left({ }^{3} \mathrm{~J}\left({ }^{195} \mathrm{Pt}-\mathrm{H}_{4}\right)\right)$ increases with the electron-withdrawing ability of the substituent $\left(50,53,54\right.$ and $56 \mathrm{~Hz}$, for bpy ${ }^{6 \mathrm{OMe}}$, bpy $^{6 \mathrm{Me}}$, bpy and $\mathrm{bpy}^{6 \mathrm{CF} 3}$, respectively). Even though several factors should be considered, it is likely that the $\mathrm{Pt}-\mathrm{C}(3)$ bond is stronger for less electron-rich heteroaromatic rings.

Table 2. ${ }^{1} \mathrm{H}$ NMR selected data. Chemical shifts are given in ppm. ${ }^{195} \mathrm{Pt}^{1}{ }^{1} \mathrm{H}$ coupling constants in parentheses.

\begin{tabular}{lccccc}
\hline & & $\mathbf{C H}_{\mathbf{3}}$ & $\mathbf{D M S O}$ & $\mathbf{H}_{\mathbf{6}^{\prime}}$ & $\mathbf{H}_{\mathbf{4}}$ \\
\hline$\left[\mathrm{Pt}\left(\mathrm{bpy}^{6 \mathrm{OMe}}-\mathrm{H}\right)(\mathrm{Me})(\mathrm{DMSO})\right]$ & $\mathbf{1 a}$ & $0.69(82)$ & $3.24(18)$ & $9.65(15)$ & $7.88(50)$ \\
\hline$\left[\mathrm{Pt}\left(\mathrm{bpy}^{6 \mathrm{Et}}-\mathrm{H}\right)(\mathrm{Me})(\mathrm{DMSO})\right]$ & $\mathbf{1 b}$ & $0.69(82)$ & $3.24(18)$ & $9.67(13.5)$ & $7.92(53)$ \\
\hline$\left[\mathrm{Pt}\left(\mathrm{bpy}^{6 \mathrm{Me}}-\mathrm{H}\right)(\mathrm{Me})(\mathrm{DMSO})\right]$ & $\mathbf{1 c}$ & $0.69(82)$ & $3.24(18.5)$ & $9.67(14)$ & $7.88(53)$ \\
\hline$\left[\mathrm{Pt}\left(\mathrm{bpy}^{6 \mathrm{CF}}-\mathrm{H}\right)(\mathrm{Me})(\mathrm{DMSO})\right]$ & $\mathbf{1 d}$ & $0.74(82)$ & $3.26(18.5)$ & $9.73(14)$ & $8.15(56)$ \\
\hline$[\mathrm{Pt}(\mathrm{bpy}-\mathrm{H})(\mathrm{Me})(\mathrm{DMSO})]$ & $\mathbf{1 e}$ & $0.70(82)$ & $3.25(18.3)$ & $9.71(14)$ & $8.01(54)$ \\
\hline
\end{tabular}

The organometallic behavior of 6-substituted 2,2'-bipyridines may be complex as several C-H bonds can be activated [49,72]. In particular, also activation of the substituent can occur, to give a terdentate $\mathrm{N}, \mathrm{N}, \mathrm{C}$ cyclometalated complex. C-H bond activation of the $\mathrm{C}(3)-\mathrm{H}$ and the substituent are in competition, especially when a 5- or 6-membered N,C cycle can be formed. The regioselectivity of the processes depends on several factors; sometimes even small changes in the structure of the ligand or in the reaction conditions can lead the reaction towards unexpected results. It seems, however, that in the case of $\mathrm{Pt}(\mathrm{II})$, electron-rich starting complexes strongly prefer the rollover process.

In the course of our previous investigations, we found that electron-poor $\mathrm{Pt}(\mathrm{II})$ derivatives react with bpy ${ }^{6 \mathrm{OMe}}$ and $\mathrm{bpy}^{6 \mathrm{Et}}$ to give the tridentate cyclometalated complexes $\left[\mathrm{Pt}\left(\mathrm{k}^{3}-\mathrm{N}, \mathrm{N}, \mathrm{C}-\mathrm{bpy}{ }^{6 \mathrm{OMe}}-\mathrm{H}\right) \mathrm{Cl}\right]$, 2a, [67], and [Pt $\left.\left(\kappa^{3}-\mathrm{N}, \mathrm{N}, \mathrm{C}-\mathrm{bpy}^{6 \mathrm{Et}}-\mathrm{H}\right) \mathrm{Cl}\right], 2 \mathbf{b}$ [73].

In order to evaluate different electronic properties ascribable to the substituent, the electrochemical behavior and electronic properties of compounds $\mathbf{1 a}$ and $\mathbf{1} \mathbf{b}$ were investigated by cyclic voltammetry and UV spectroscopy, respectively. The electrochemical behavior of both complexes was investigated in $\mathrm{TEAPF}_{6} / \mathrm{CH}_{2} \mathrm{Cl}_{2}$ solvent system, at a potential scan rate equal to $100 \mathrm{mV} \mathrm{s}^{-1}$. No cathodic process is evidenced in the experimental conditions. 
The voltammetric response of 1 a shows an anodic, irreversible process located at $1.29 \mathrm{~V}$ (Figure 3). The evaluation of the onset potential allowed the determination of the energy value of HOMO (highest occupied molecular orbital) $(-5.59 \mathrm{eV})$. The comparison with literature data [74] suggests that the anodic process is due to a mono-electronic EC (electrochemical-chemical) transfer. The main reason for the irreversibility of the process is the instability of the formally $\mathrm{Pt}(\mathrm{III})$ derivative. Indeed, usually anodic process on $\mathrm{Pt}(\mathrm{II})$ derivatives are attributed mainly to the metal center [75]. Nevertheless, according to our previous evaluation on the parent derivative [Pt(bpy-H)(Me)DMSO)] 1e [76], we can hypothesize that the anodic process involves mainly the bpy ligand and, to a minor extent, the metal center.
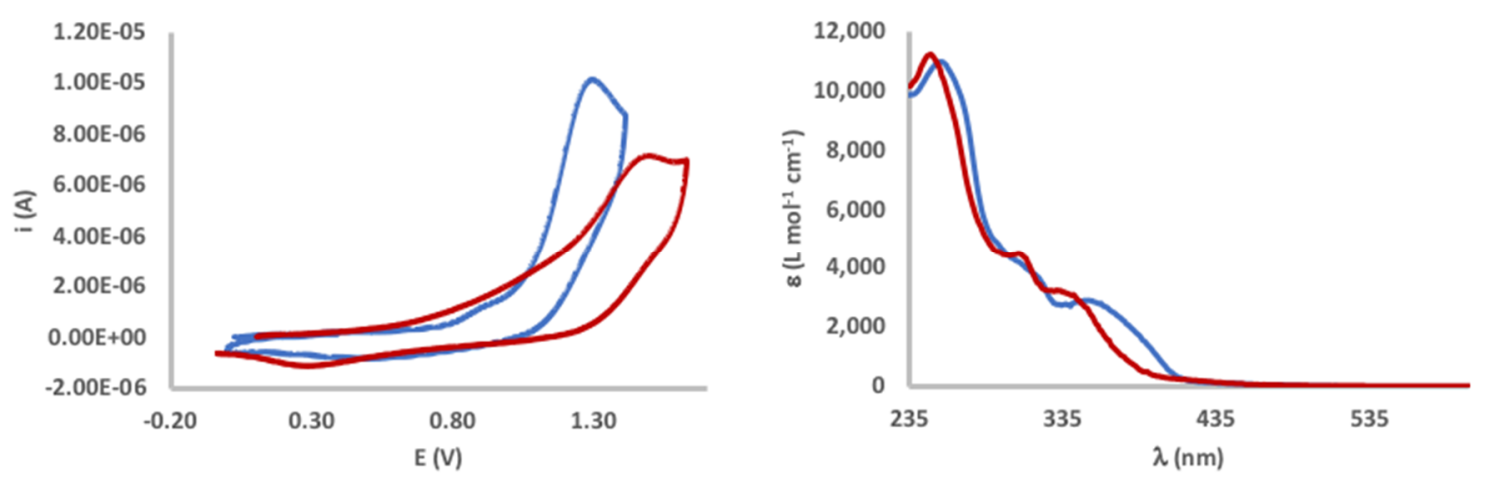

Figure 3. Cyclic voltammetry curves (on the left) and UV-Vis spectra (on the right) of $\left[\mathrm{Pt}\left(\mathrm{bpy}^{6 \mathrm{OMe}}-\mathrm{H}\right)(\mathrm{Me})(\mathrm{DMSO})\right]\left(\mathbf{1 a}\right.$, blue) and $\left[\mathrm{Pt}\left(\mathrm{bpy}^{6 \mathrm{Et}}-\mathrm{H}\right)(\mathrm{Me})(\mathrm{DMSO})\right](\mathbf{1} \mathbf{b}$, red).

The voltammetric response of $\mathbf{1 b}$ (Figure 3) shows an irreversible, broad anodic process located at more positive potential values (between $1.4 \mathrm{~V}$ and $1.5 \mathrm{~V}$ ), characterized by an evidently poor reproducibility. As a consequence, in the case of $1 \mathrm{~b}$ it is possible to approximately estimate the energy of the HOMO (about $-5.4 \mathrm{eV}$ ).

The scarce reproducibility of the response of $\mathbf{1} \mathbf{b}$ does not allow accurate comparison between the two complexes and the parent unsubstituted-bpy derivative. In either case, we can observe (Table 3) that the bpy ${ }^{6 \mathrm{Et}}$ cyclometalated complex appears more stable than the corresponding bpy ${ }^{6 \mathrm{OMe}}$ derivative, which in turn is more stable than the bpy one.

Table 3. Optical and electrochemical data.

\begin{tabular}{|c|c|c|c|c|c|}
\hline & $\lambda(\mathrm{nm})^{a}$ & $E_{g, o p t}(e V)^{b}$ & $E_{o x}(V)^{c}$ & $\operatorname{HOMO}(e V)^{d}$ & LUMO $(\mathrm{eV})^{\mathrm{e}}$ \\
\hline$\left[\mathrm{Pt}\left(\mathrm{bpy} \mathrm{OMe}_{-\mathrm{H}}\right)(\mathrm{Me})(\mathrm{DMSO})\right] \mathbf{1 a}$ & 255,352 & 3.03 & 1.29 & -5.59 & -2.56 \\
\hline$\left[\mathrm{Pt}\left(\mathrm{bpy}^{\mathrm{Et}}{ }_{-\mathrm{H}}\right)(\mathrm{Me})(\mathrm{DMSO})\right] \mathbf{1 b}$ & $249,309,340$ & 3.14 & $1.4-1.5$ (broad) & $-5.4 c a{ }^{\mathrm{f}}$ & $-2.3 c a .{ }^{f}$ \\
\hline$[\mathrm{Pt}(\mathrm{bpy}-\mathrm{H})(\mathrm{Me})(\mathrm{DMSO})] \mathbf{1 e}$ & $276,307,380$ & 2.99 & 0.72 & -5.13 & -2.14 \\
\hline
\end{tabular}

${ }^{a}$ In $\mathrm{CH}_{2} \mathrm{Cl}_{2}$ solution; concentration about $7 \times 10^{-5} \mathrm{M} .{ }^{\mathrm{b}}$ The Energy-gap $\left(\mathrm{E}_{\mathrm{g}, \mathrm{opt}}\right)$ value was determined from the $\lambda_{\text {onset }}$ in the UV-Vis spectrum. ${ }^{c}$ Potential values reported vs. $\mathrm{Ag} / \mathrm{AgCl}$ in $\mathrm{CH}_{2} \mathrm{Cl}_{2}-\mathrm{TEAPF}_{6} 0.1 \mathrm{M}$ solvent system. Concentration about $2.5 \times 10^{-3} \mathrm{M}$. ${ }^{\mathrm{d}}$ Calculated from the anodic onset potential value. ${ }^{\mathrm{e}}$ Calculated from the equation $\mathrm{LUMO}(\mathrm{eV})=\mathrm{HOMO}+\mathrm{E}_{\mathrm{g}, \mathrm{opt}}[77] .{ }^{\mathrm{f}}$ Due to the scarce reproducibility of the voltammetric response, only an approximate evaluation of the HOMO can be calculated.

A comparison between the HOMO values of the parent species $\mathbf{1 e}$ and the derivative $\mathbf{1 b}$ confirms that the presence of the -Et substituent on the bpy ligand induces a stabilization of the HOMO. Despite the trend observed in anodic potential values, the HOMO in $\mathbf{1 a}$ is lower in energy than in $\mathbf{1 b}$ and in 1e. Such apparently anomalous behavior can be ascribed to the mixed $-\mathrm{I} /+\mathrm{M}$ electron effect of the -OMe substituent.

The UV-Vis spectra in $\mathrm{CH}_{2} \mathrm{Cl}_{2}$ (Figure 3 and Table 3) is evidence of the presence of higher energy bands, attributed to ligand-centered transitions $\left(p \rightarrow p^{*}\right)$ located on the $b p y^{6 R}$ ligand. Furthermore, $\mathrm{d}_{\mathrm{Pt}} \rightarrow \mathrm{p}^{*}$ metal-to-ligand charge transfer mixed with intra-ligand transitions are present at 
lower energy. In addition, a blue shift in the MLCT (metal to ligand charge transfer) band going from bpy to bpy ${ }^{6 \mathrm{OMe}}$ to bpy ${ }^{6 \mathrm{Et}}$ is observed, suggesting an increasing s-donor effect according to this trend.

Finally, the energy gap values $\left(E_{\mathrm{g}, \mathrm{opt}}\right.$ ) were calculated from the UV-Vis spectra, showing an increasing trend along the series $\mathbf{1 b}>\mathbf{1 a}>\mathbf{1 e}$. The LUMO energies obtained from the experimental $\mathrm{E}_{\mathrm{g}, \mathrm{opt}}$ and HOMO values [77] suggest that the increasing in $\mathrm{E}_{\mathrm{g}, \mathrm{opt}}$ is due to a stabilization both of the highest occupied and of the lower unoccupied molecular orbitals. The frontier orbitals of the investigated compounds are depicted in Figure 4. Within the same series (e.g., HOMO for 1a-e) both the HOMO and LUMO are qualitatively similar. The HOMO of protonated species 3a-e (see later) is mainly localized on the platinum atom.

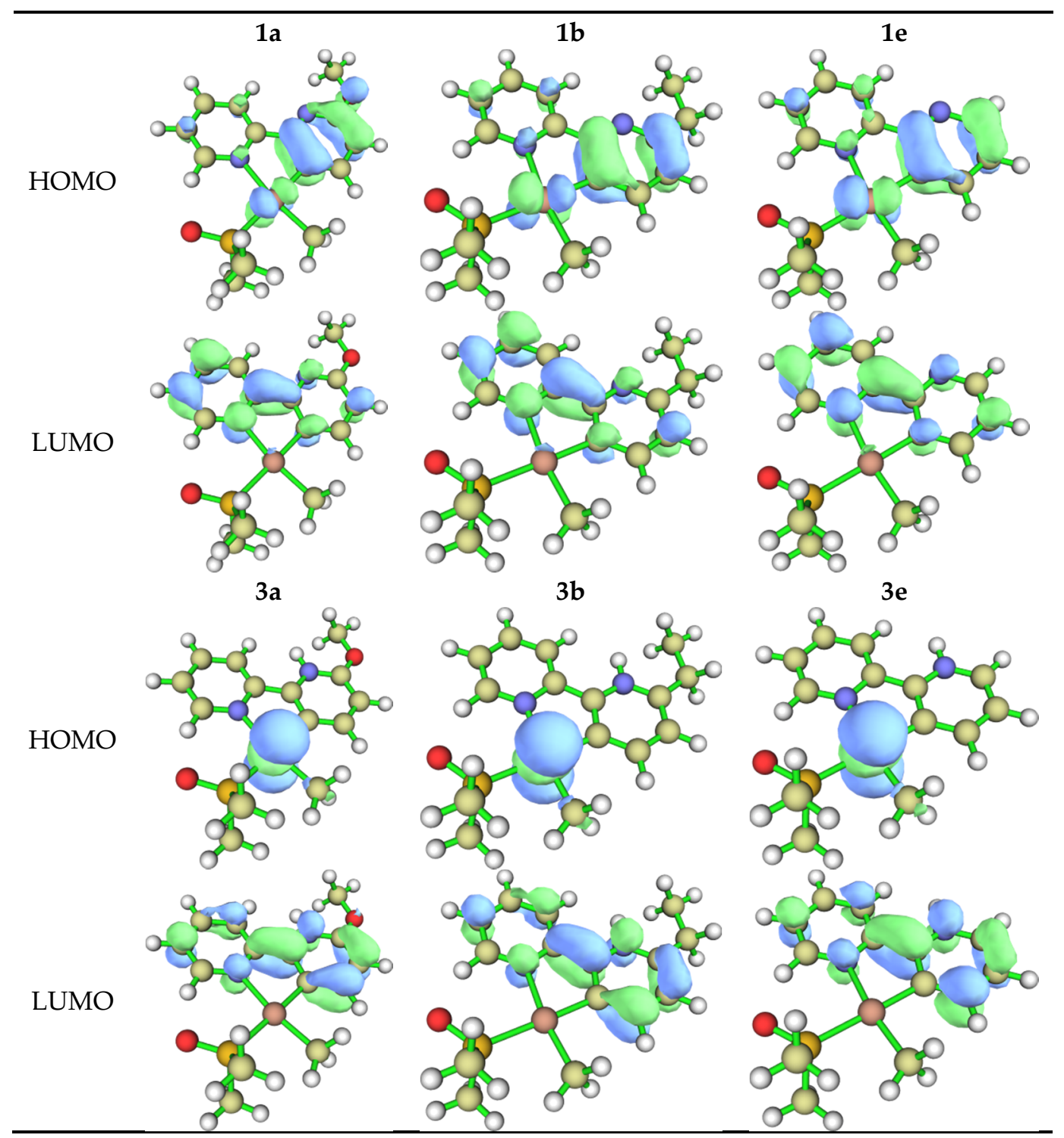

Figure 4. Frontier molecular orbitals of neutral complexes $\mathbf{1 a}, \mathbf{1 b}$ and $\mathbf{1 e}$ and corresponding protonated complexes $\mathbf{3 a}, \mathbf{3 b}$ and $\mathbf{3 e}$.

\subsection{Reactivity with Acids}

One of the most important features of rollover complexes derived from 2,2'-bipyridines is the presence of an uncoordinated nitrogen atom, able to act as a Lewis base. As reported by us and by other groups $[37,78,79]$, the reactivity of $\mathrm{Pt}(\mathrm{II})$ rollover complexes with electrophiles may be complex, due to 
the presence of several centers able to act as nucleophiles: the uncoordinated nitrogen, the electron-rich platinum center, and the two Pt-C bonds.

In the case of nitrogen protonation, the resulting neutral bipyridine ligand, reported in this paper as bpy*, is an isomer of the corresponding bipyridine, and should be considered either as a mesoionic ligand or an abnormal remote carbene, being a 3-pyridylene ligand (Figure 5) [21-25].
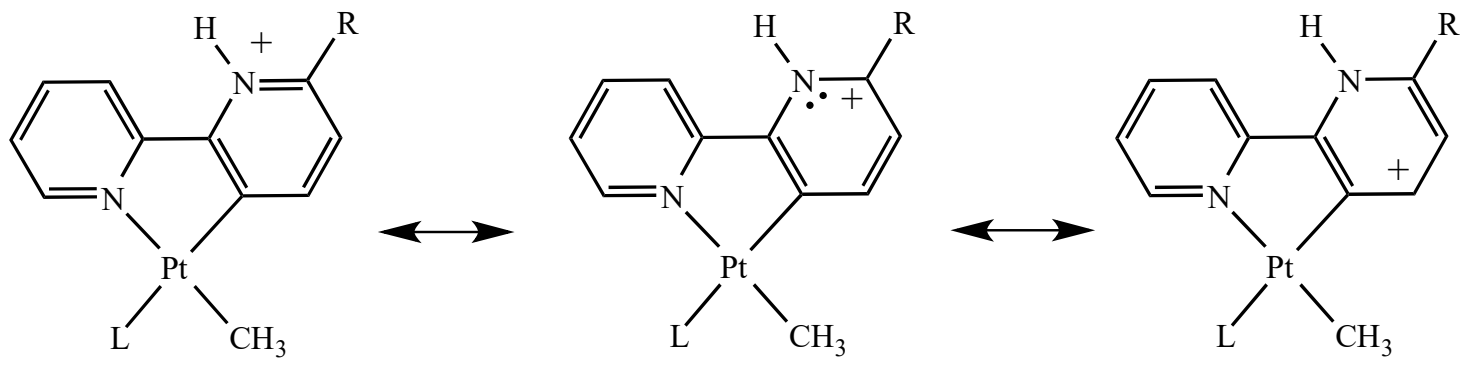

Figure 5. Some resonance forms of a pyridylene complex $\left[\mathrm{Pt}\left(\mathrm{bpy}^{6 \mathrm{R} *}\right)\left(\mathrm{CH}_{3}\right) \mathrm{L}\right]^{+}$.

Two different situations were studied: reaction with a strong acid bearing a weakly coordinating anion, $\left[\mathrm{H}_{3} \mathrm{O} \cdot 18\right.$-crown-6] $\left[\mathrm{BF}_{4}\right]$, and reaction with $\mathrm{HCl}$, having, at variance, a strongly coordinating anion. As expected, the reaction proceeded differently in the two cases, also depending on the nature of the neutral and anionic ligands $\left(\mathrm{PPh}_{3}\right.$ vs. DMSO and $\left.\mathrm{Me} v \mathrm{vs} . \mathrm{Cl}\right)$ as well as the substituent of the bipyridine ligand.

The protonation reactions were performed under mild conditions, e.g., acetone at room temperature.

The behavior towards acids of complexes $\mathbf{1 a}$ and $\mathbf{1 b}$ is very different. Complex $\mathbf{1 b}$ is easily protonated at the free nitrogen to give the stable cationic pyridylene complex $\left[\mathrm{Pt}\left(\mathrm{bpy}^{6 \mathrm{Et} *}\right)(\mathrm{Me})(\mathrm{DMSO})\right]^{+}$, $3 \mathbf{b}$, which can be isolated in the solid state as its $\mathrm{BF}_{4}$ salt $3 \mathrm{~b}-\mathrm{BF}_{4}$ (Figure 6). The neutral ligand bpy ${ }^{6 \mathrm{Et} *}$ is both a mesoionic isomer of free bpy ${ }^{6 \mathrm{Et}}$ and an abnormal 3-pyridylene [21-25]. This behavior brings rollover-cyclometalated 6-ethyl-2,2'-bipyridine ligand into the class of "ligands with multiple personalities", i.e., ligands that, far from being simple spectators in reactions, can enhance or modify the reactivity of the metal center after protonation, deprotonation or other simple acts [20].
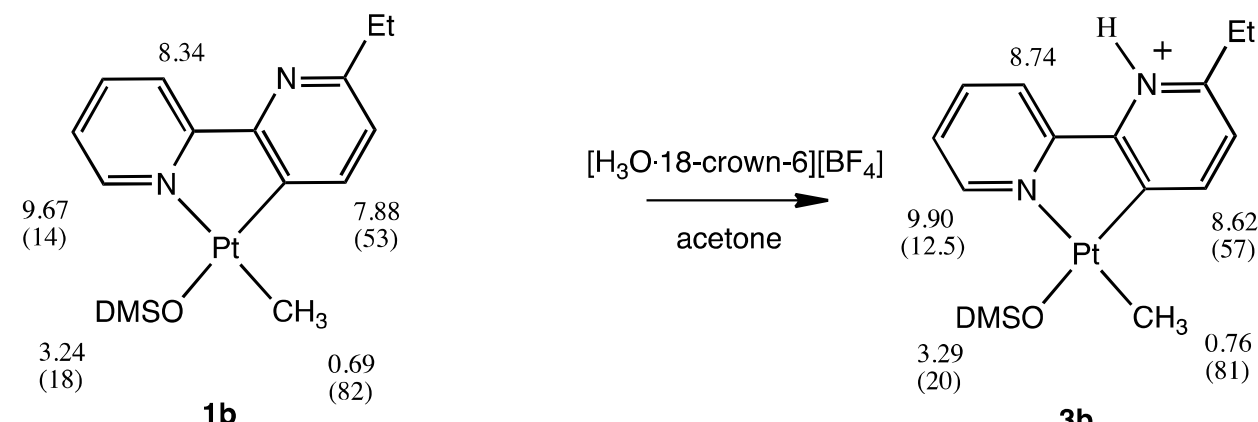

$\mathrm{BF}_{4}^{-}$

Figure 6. Protonation of complex $\mathbf{1 b}$ to give the abnormal-remote pyridylene complex $\mathbf{3 b}$. Chemical shifts and coupling constants (in parenthesis) are reported for notable protons.

Complex $3 \mathbf{b}$ has been characterized by means of microanalysis and ${ }^{1} \mathrm{H}$ NMR spectroscopy. The ${ }^{1} \mathrm{H}$ NMR spectrum clearly shows the $\mathrm{N}-\mathrm{H}$ proton as a broad singlet at $\delta=13.3$ which disappears after treatment with $\mathrm{D}_{2} \mathrm{O}$. In addition, all the aromatic signals are shifted to lower fields with respect to $\mathbf{1 b}$ (e.g., 3b: $\mathrm{H}_{4}, \delta=8.62 \mathrm{ppm},{ }^{3} \mathrm{~J}_{\mathrm{Pt}-\mathrm{H}}=57 \mathrm{~Hz} ; \mathrm{H}_{6^{\prime}}, \delta=9.90 \mathrm{ppm},{ }^{3} \mathrm{~J}_{\mathrm{Pt}-\mathrm{H}}=12.5 \mathrm{~Hz} ; \mathbf{1 b}: \mathrm{H}_{4}, \delta=7.88 \mathrm{ppm}$, ${ }^{3} \mathrm{~J}_{\mathrm{Pt}-\mathrm{H}}=53 \mathrm{~Hz} ; \mathrm{H}_{6^{\prime}}, \delta=9.67 \mathrm{ppm},{ }^{3} \mathrm{~J}_{\mathrm{Pt}-\mathrm{H}}=14 \mathrm{~Hz}$ ). The noteworthy low field shift of the $\mathrm{H}_{4}$ proton $(+0.74 \mathrm{ppm})$ is also a good indicator of protonation. Its coupling constant with the ${ }^{195} \mathrm{Pt}$ nucleus $\left({ }^{3} \mathrm{~J}_{\mathrm{Pt}-\mathrm{H}}\right.$ $=57 \mathrm{~Hz})$ is also larger than that in the parent complex $1 \mathbf{b}\left({ }^{3} \mathrm{~J}_{\mathrm{Pt}-\mathrm{H}}=53 \mathrm{~Hz}\right)$ as expected for a decreased 
donor ability of the metalated carbon. The low field shift of the $\mathrm{H}_{3^{\prime}}$ proton (from $8.34 \mathrm{ppm}$ in $\mathbf{1 b}$ to $8.74 \mathrm{ppm}$ in $3 \mathbf{b}, \Delta \delta=+0.40 \mathrm{ppm}$ ) may be linked to the presence of the nearby $\mathrm{N}-\mathrm{H}$ proton.

Furthermore, the presence of ${ }^{195} \mathrm{Pt}$ satellites for the $\mathrm{H}_{4}, \mathrm{H}_{5}$ and $\mathrm{H}_{6^{\prime}}$ protons demonstrates that the ligand is still coordinated to platinum center, as well as the DMSO and methyl groups (DMSO: singlet with satellites at $\delta=3.29 \mathrm{ppm},{ }^{3} \mathrm{JPt}-\mathrm{H}=20.3 \mathrm{~Hz}$; methyl: singlet with satellites at $\delta=0.76 \mathrm{ppm}$, $\left.{ }^{2} \mathrm{JPt}_{\mathrm{Pt}}=80.8 \mathrm{~Hz}\right)$.

It is worth noting that the corresponding $\left[\mathrm{Pt}\left(\mathrm{bpy}^{6 \mathrm{Et}}-\mathrm{H}\right)(\mathrm{Me})(\mathrm{DMSO})\right] /\left[\mathrm{Pt}\left(\mathrm{bpy}^{6 \mathrm{Et} *}\right)(\mathrm{Me})(\mathrm{DMSO})\right]^{+}$ complexes, $\mathbf{1 b} / \mathbf{3 b}$, constitute an uncommon Brønsted-Lowry acid-base conjugated couple.

Protonation reactions of this type are of potential interest. Recently, protonation and deprotonation of the $\operatorname{Ir}(\mathrm{III})$ rollover complex $\left[\operatorname{Ir}\left(\mathrm{PPh}_{3}\right)_{2}(\mathrm{bpy}-\mathrm{H})(\mathrm{Cl})(\mathrm{H})\right]$ lead to reversible switching of the emission (from bluish-green to yellowish-orange and vice versa), demonstrating that it is an "aggregation induced phosphorescence" (AIP) active rollover complex, able to act as a multi-stimuli responsive luminescence material [36].

This easy protonation is likely due to the good basicity of the uncoordinated nitrogen atom and to a not excessive electron density on the $\mathrm{Pt}$ atom. The $\mathrm{Pt}-\mathrm{C}\left(\mathrm{sp}^{2}\right)$ and $\mathrm{Pt}-\mathrm{C}\left(\mathrm{sp}^{3}\right)$ bonds appear to be fairly stable under these conditions.

In contrast, no signs of protonation were detected in the reaction of complex 1a. The reaction was also followed by means of ${ }^{1} \mathrm{H}$ NMR spectroscopy, observing rapid liberation of methane (a singlet at $0.18 \mathrm{ppm}$ ) and no signs of $\mathrm{N}-\mathrm{H}$ protons. The $\mathrm{Pt}_{-} \mathrm{CH}_{3}$ signal disappears with the appearance of methane. The spectra showed the presence of several species in solution which we were not able to identify. Even isolation in the solid state of the reaction products did not allow us to characterize the formed species. It seems, overall, that in the case of complex 1a, electrophilic attack occurs on the $\mathrm{Pt}$ center or on the $\mathrm{Pt}-\mathrm{CH}_{3}$ bond. The resulting liberation of methane leads to unstable species and, finally, to decomposition.

The different behavior of the two bipyridine ligands is likely due to the scarce basicity of the uncoordinated nitrogen in bpy ${ }^{6 \mathrm{OMe}}$ combined to a higher electron density on the Pt center. In addition, the planar configuration induced by metalation reduces the availability of the nitrogen lone pair due to the proximity of the $\mathrm{C}\left(3^{\prime}\right)$-H hydrogen.

The reaction of complexes $\mathbf{1 a}-\mathbf{b}$ with $\mathrm{HCl}$ is different from that with $\left[\mathrm{H}_{3} \mathrm{O} \cdot 18\right.$-crown-6][ $\left.\mathrm{BF}_{4}\right]$. It is worth noting that in this case $\mathbf{1 a}$ and $\mathbf{1 b}$ react in the same way, leading to methane elimination and formation of the corresponding chloride derivatives $\left[\mathrm{Pt}\left(\mathrm{bpy}^{6 \mathrm{R}}-\mathrm{H}\right) \mathrm{Cl}(\mathrm{DMSO})\right](\mathrm{R}=\mathrm{OMe}, \mathbf{4 a} ; \mathrm{R}=\mathrm{Et}, \mathbf{4 b})$, which can be isolated with good yields and characterized.

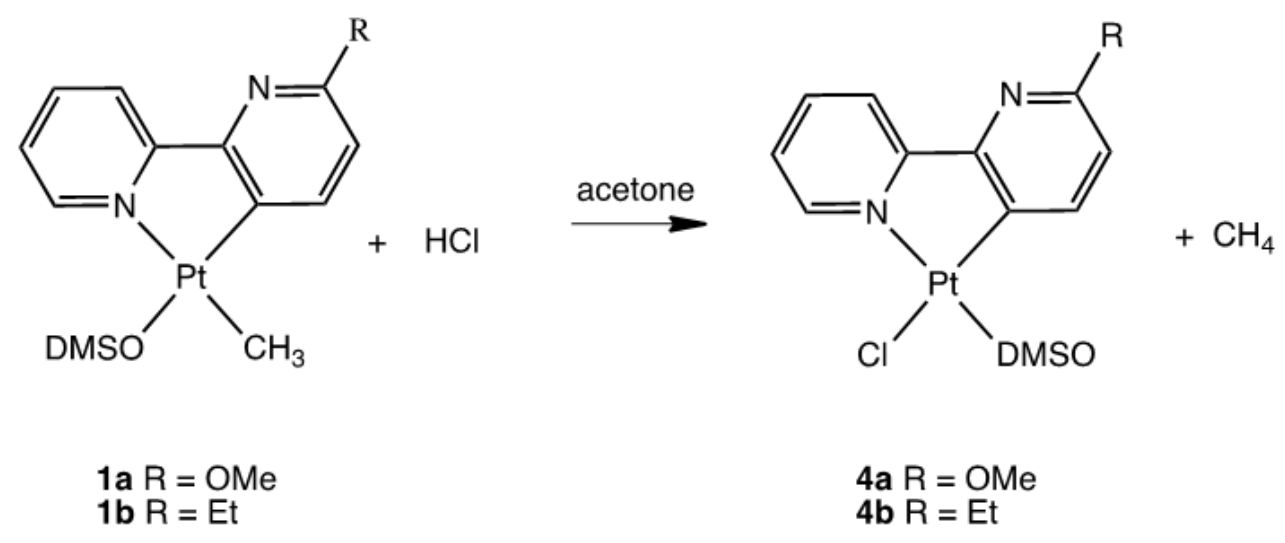

Synthesis of $\mathbf{4 a}$ and $\mathbf{4 b}$

The reaction process can be simplified following a "one pot" procedure, reacting [ $\left.\mathrm{Pt}(\mathrm{DMSO})_{2} \mathrm{Me}_{2}\right]$ with bpy ${ }^{6 \mathrm{R}}$ at $50^{\circ} \mathrm{C}$ and adding $\mathrm{HCl}$ after the rollover reaction has taken place.

The ${ }^{1} \mathrm{H}$ NMR spectrum allows an easy characterization of the products. In particular, the signal of the coordinated DMSO, coupled to ${ }^{195} \mathrm{Pt}$, indicates a trans N-Pt-DMSO disposition, as suggested by the 
high value of ${ }^{3} \mathrm{~J}(\mathrm{Pt}-\mathrm{H}), 23.6$ and $23.3 \mathrm{~Hz}$ for $\mathbf{4 a}$ and $\mathbf{4 b}$, respectively, to be compared to 18.2 and $18.1 \mathrm{~Hz}$ in $\mathbf{1 a}$ and $\mathbf{1 b}$.

In this case, the reaction likely involves a $\mathrm{Cl}$-assisted mechanism, which may proceed through an oxidative addition/reductive elimination pathway. In an oxidative-addition ionic mechanism, halide ion attack and protonation occur separately. In the two possible pathways either protonation of the metal or coordination of chloride may be the first step [80].

Complexes $4 \mathbf{a}-\mathbf{b}$ were tested with $\left[\mathrm{H}_{3} \mathrm{O} \cdot 18\right.$-crown-6][ $\left.\mathrm{BF}_{4}\right]$ in the same conditions as $\mathbf{1 a}-\mathbf{b}(1 \mathrm{~h}$, r.t. in acetone solution). The outcome of the reaction of the chloride species is, also in this case, different for the two complexes.

Under mild reaction conditions complex 4 a reacts only slightly with $\left[\mathrm{H}_{3} \mathrm{O} \cdot 18\right.$-crown-6] $\left[\mathrm{BF}_{4}\right]$, showing that the free nitrogen is not available for protonation and the $\mathrm{Pt}-\mathrm{C}\left(\mathrm{sp}^{2}\right)$ bond is fairly stable. No signs of $\mathrm{N}-\mathrm{H}$ protons are visible in the spectra and only a few amounts of a secondary species can be detected by NMR spectroscopy. Analysis of the signals indicate that the trace species is not a protonated complex, but we were not able to characterize the secondary compound.

In contrast, the chloride derivative $4 \mathrm{~b}$, in line with the behavior of the corresponding methyl complex $\mathbf{1 b}$, is easily protonated at the uncoordinated nitrogen, to give also in this case the mesoionic cationic species $\left[\mathrm{Pt}\left(\mathrm{bpy}^{6 \mathrm{Et} *}\right)(\mathrm{Cl})(\mathrm{DMSO})\right]^{+}, \mathbf{5 b}$, (isolated in the solid state as its $\mathrm{BF}_{4}$ salt).

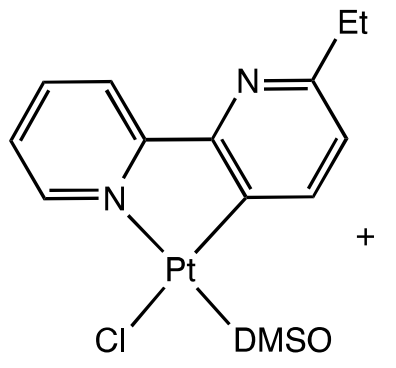

4b

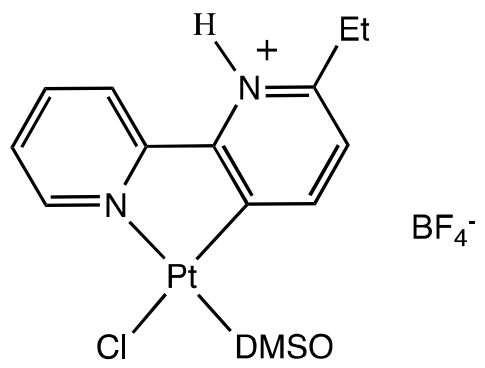

$5 b$

Also in this case, the ${ }^{1} \mathrm{H}$ NMR confirm the protonation showing a broad signal at $13.3 \mathrm{ppm}$. All the other signals are downfield shifted. In particular, the diagnostic signals of the $\mathrm{H}_{4}$ and $\mathrm{H}_{3^{\prime}}$ protons are shifted downfield to 0.90 and $0.39 \mathrm{ppm}$, respectively.

The stereoelectronic properties of the starting rollover complexes $\mathbf{1 a}-\mathbf{b}$ can be modified by substitution of the ancillary ligands. Starting from complexes $\mathbf{1} \mathbf{a}-\mathbf{b}$ and $\mathbf{4 a}-\mathbf{b}$, subsequent substitution reactions with $\mathrm{PPh}_{3}$ yields the corresponding phosphine complexes: $\left[\mathrm{Pt}\left(\mathrm{bpy}{ }^{6 \mathrm{OMe}}-\mathrm{H}\right)(\mathrm{Me})\left(\mathrm{PPh}_{3}\right)\right], \mathbf{6 a}$, previously reported by some of us [71], [Pt(bpy $\left.\left.{ }^{6 \mathrm{Et}}-\mathrm{H}\right)(\mathrm{Me})\left(\mathrm{PPh}_{3}\right)\right], \mathbf{6 b},\left[\mathrm{Pt}\left(\mathrm{bpy}^{6 \mathrm{OMe}}-\mathrm{H}\right)(\mathrm{Cl})\left(\mathrm{PPh}_{3}\right)\right], 7 \mathbf{a}$, and $\left[\mathrm{Pt}\left(\mathrm{bpy}^{6 \mathrm{Et}}-\mathrm{H}\right)(\mathrm{Cl})\left(\mathrm{PPh}_{3}\right)\right], 7 \mathrm{~b}$.

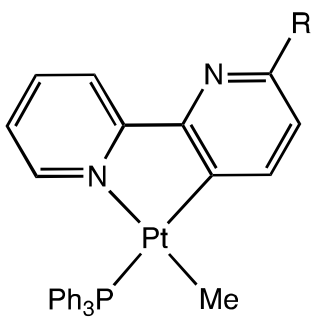

$\mathbf{R}=\mathbf{O M e}, \mathbf{6 a}$
$\mathbf{R}=\mathbf{E t}, \mathbf{6 b}$

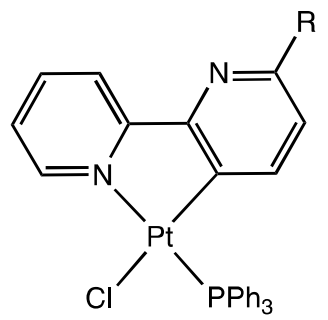

$\mathbf{R}=\mathbf{O M e}, 7 \mathrm{a}$

$\mathbf{R}=\mathbf{E t}, \quad 7 \mathbf{b}$

The ${ }^{31} \mathrm{P}$ NMR of complexes 6 and 7 clearly demonstrate the substitution of DMSO with $\mathrm{PPh}_{3}$. The coordination of $\mathrm{PPh}_{3}$ reflects the position of DMSO in the parent complex, i.e., in trans position to 
$\mathrm{C}(3)$ in complexes $\mathbf{6} \mathbf{a}-\mathbf{b}$ and trans to $\mathrm{N}$ in complexes $\mathbf{7 a}-\mathbf{b}$, as shown by the ${ }^{31} \mathrm{P} N M R$ spectra (e.g., $\mathbf{6 a}$ : $\delta=32.59 \mathrm{ppm}, \mathrm{J}_{\mathrm{Pt}-\mathrm{P}}=2257 \mathrm{~Hz}, 6 \mathbf{b}: \delta=32.71 \mathrm{ppm}, \mathrm{J}_{\mathrm{Pt}-\mathrm{P}}=2221 \mathrm{~Hz}$, in agreement with P-trans-C; $7 \mathrm{a}:$ $\delta=22.31 \mathrm{ppm}, \mathrm{J}_{\mathrm{Pt}-\mathrm{P}}=4245 \mathrm{~Hz}, 7 \mathrm{~b}: \delta=22.61 \mathrm{ppm}, \mathrm{J}_{\mathrm{Pt}-\mathrm{P}}=4297 \mathrm{~Hz}$, in agreement with P-trans-N). Notably, the Pt-P coupling constant is greater in $\mathbf{6 a}$ then in $\mathbf{6 b}$, whereas the opposite happens for $\mathbf{7 a}$ and $\mathbf{7 b}$, showing an interesting combination of cis and trans influences.

In addition to these data, the ${ }^{1} \mathrm{H}$ NMR spectra of $\mathbf{6 a}$ and $\mathbf{6} \mathbf{b}$ show a doublet with satellite for the coordinated methyl protons, due to coupling with ${ }^{31} \mathrm{P}$ and ${ }^{195} \mathrm{Pt}$ nuclei (e.g., 6a: $\delta 0.73 \mathrm{ppm}$, ${ }^{2} \mathrm{~J}_{\mathrm{Pt}-\mathrm{H}}=82.8 \mathrm{~Hz},{ }^{3} \mathrm{~J}_{\mathrm{P}-\mathrm{H}}=7.8 \mathrm{~Hz}$ ). Furthermore, the $\mathrm{H}_{6^{\prime}}$ in $\mathbf{6} \mathbf{a}-\mathbf{b}$ and the $\mathrm{H}_{4}$ in $\mathbf{7 a} \mathbf{a}-\mathbf{b}$ appear strongly shielded, due to the anisotropic effect of the adjacent phenyl rings of $\mathrm{PPh}_{3}$.

The phosphine complexes $\mathbf{6} \mathbf{a}-\mathbf{b}$ and $\mathbf{7 a}-\mathbf{b}$ were reacted with acids in order to analyze the influence of $\mathrm{PPh}_{3}$ on the reactivity. Due to the better donor properties of $\mathrm{PPh}_{3}$ compared to DMSO, compounds 6 and $\mathbf{7}$ are expected to have a higher electron density on the Pt center than the corresponding species 1 and 4 .

First, the reaction with $\left[\mathrm{H}_{3} \mathrm{O}-18\right.$-crown-6][ $\left.\mathrm{BF}_{4}\right]$ was studied. In contrast to complex 1a, $\mathbf{6 a}$ reacts in a clean way with the acid to give the cationic adduct $\left[\mathrm{Pt}\left(\mathrm{bpy}^{6 \mathrm{OMe}}\right)(\mathrm{Me})\left(\mathrm{PPh}_{3}\right)\right]^{+}$. This reaction consists in a "retro-rollover" process, where the $\mathrm{C}_{3}$-Pt bond is attacked by the acid and, after rotation of the internal bipyridine $\mathrm{C}-\mathrm{C}$ bond, a $\mathrm{k}^{2}-\mathrm{N}, \mathrm{N}$ complex is formed.

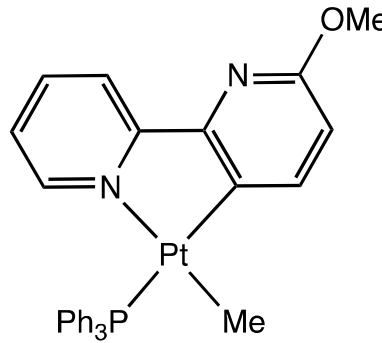

6a

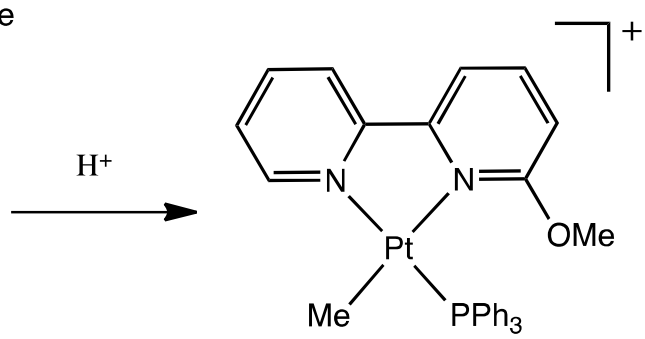

$\mathbf{8 a}$

It is worth noting that the analogous DMSO complex 1a reacts on the other Pt-C bond, the Pt- $\mathrm{CH}_{3}$ one, releasing methane. In the more electron-rich complex 6a, at variance, the $\mathrm{Pt}-\mathrm{C}\left(\mathrm{sp}^{2}\right)$ bond is attached. No evidence of nitrogen protonation was achieved also in this case. The reaction proceeds very fast; as previously reported by some of us, the retro-rollover reaction of similar complexes is faster with better electron-donors $\left(\mathrm{PCy}_{3}>\mathrm{PPh}_{3}>\mathrm{P}(\mathrm{OPh})_{3}\right)$ [76]. In this case, the combined donor properties of $\mathrm{PPh}_{3}$ and bpy ${ }^{6 \mathrm{OMe}}$ may be responsible for the reaction outcome.

The retro-rollover process should lead in principle to two geometric isomers, one with the OMe substituent in cis position to the Me and the other one in trans. Only one isomer, however, is formed during the reaction and can be isolated in the solid state. An extended 1D and 2D NMR investigation, by means of ${ }^{1} \mathrm{H},{ }^{31} \mathrm{P},{ }^{1} \mathrm{H}$ COSY and ${ }^{1} \mathrm{H}$ NOESY spectra, indicate that the isolated species correspond to the less sterically favored isomer, i.e., that with the bulky $\mathrm{PPh}_{3}$ in cis to the methoxy substituent.

The ${ }^{31} \mathrm{P}$ NMR shows a singlet with satellites in line with a P-trans-N arrangement $(\delta=17.40 \mathrm{ppm}$, ${ }^{1} \mathrm{~J}_{\mathrm{Pt}-\mathrm{P}}=4510 \mathrm{~Hz}$ ). The ${ }^{1} \mathrm{H}$ NMR shows all the expected aromatic protons and the ${ }^{1} \mathrm{H}$ NOESY shows correlations between $\mathrm{OCH}_{3}$ and $\mathrm{H}_{\text {orto }}$ of $\mathrm{PPh}_{3}$ (signals at 2.61 and 7.76 ppm) as well as with $\mathrm{H}_{5}$ (6.79 ppm). Furthermore, the coordinated methyl at $0.64 \mathrm{ppm}$ shows contacts with the $\mathrm{H}_{\text {ortho }} \mathrm{PPh}_{3}$ protons and $\mathrm{H}_{6^{\prime}}$ (7.76 and $8.86 \mathrm{ppm}$, respectively, Figure 7).

An analogous retro-rollover process was observed for rollover complexes derived from 2-(2'-pyridyl)quinoline (pyqui). In that case, however, two geometric isomers of the cationic adduct $\left[\mathrm{Pt}\left(\text { pyqui) }(\mathrm{Me})\left(\mathrm{PPh}_{3}\right)\right]^{+}\right.$were observed in solution and isolated in the solid state as $\mathrm{BF}_{4}$ salts [76].

The behavior of rollover complexes derived from pyqui is, once again, different from that of bpy $^{6 \mathrm{OMe}}$ and bpy ${ }^{6 \mathrm{Et}}$ : the DMSO complex [Pt(pyqui-H)(DMSO)Me], 1d, is easily nitrogen-protonated to give the stable mesoionic species $\left[\mathrm{Pt}\left(\text { pyqui }^{*}\right)(\mathrm{Me})(\mathrm{DMSO})\right]^{+}$, whereas $\left[\mathrm{Pt}\left(\right.\right.$ pyqui-H)(Me) $\left.\left(\mathrm{PPh}_{3}\right)\right]$, 
6d, is protonated as well, to give $\left[\mathrm{Pt}\left(\mathrm{pyqui}^{*}\right)(\mathrm{Me})\left(\mathrm{PPh}_{3}\right)\right]^{+}$, stable and isolable in the solid state as $\mathrm{BF}_{4}$ salt. In solution $\left[\mathrm{Pt}\left(\text { pyqui }^{*}\right)(\mathrm{Me})\left(\mathrm{PPh}_{3}\right)\right]^{+}$slowly (2 days) follows a retro-rollover process to give $\left[\mathrm{Pt}\left(\text { pyqui) }(\mathrm{Me})\left(\mathrm{PPh}_{3}\right)\right]^{+}\right.$as a couple of isomers [76].

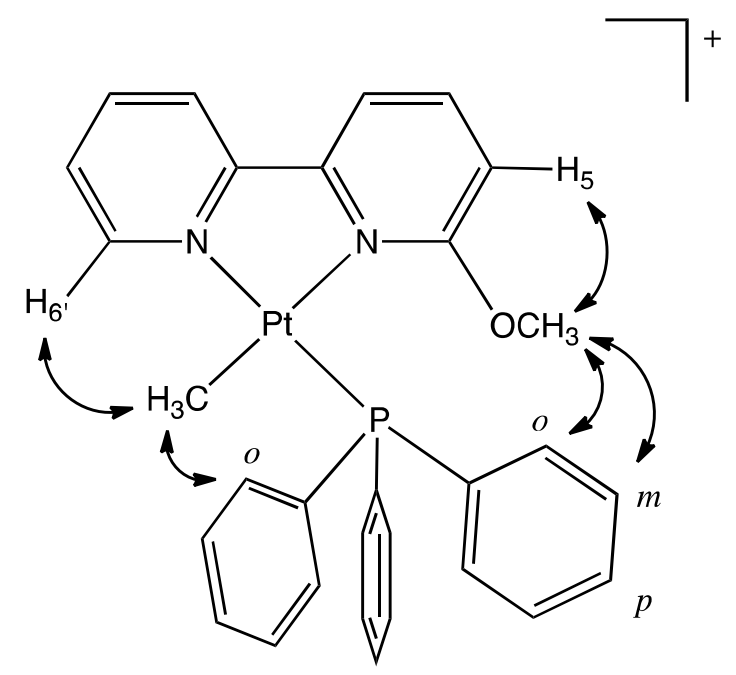

Figure 7. ${ }^{1} \mathrm{H}$ NOE contacts in complex 8 a.

The isolation of only one isomer in the case of $\mathrm{bpy}^{6 \mathrm{OMe}}$ may be attributed to a different reaction pathway or to a higher stability of the observed isomer due to electronic factors. It may be assumed that the methoxy substituent influences the adjacent nitrogen reducing its donor properties and, as a consequence, the ligand with the highest trans-influence, i.e., the methyl, places itself in trans to the donor with the worst trans-influence, i.e., the nitrogen of the substituted pyridine ring, to give the most stable isomer. In agreement, the ${ }^{3} \mathrm{~J}_{\mathrm{Pt}-\mathrm{H}}$ coupling constant of the coordinated methyl protons $(74 \mathrm{~Hz})$ is larger than that found in the analogous $2,2^{\prime}$-bipyridine complexed $(69 \mathrm{~Hz})$, suggesting a stronger $\mathrm{Pt}-\mathrm{CH}_{3}$ bond.

In order to shed more light on the observed outcome of the reaction we performed a series of DFT calculations. The two potential isomers, i.e., $\mathrm{PPh}_{3}$ cis (8a) or trans (8a-iso) to the substituted pyridine ring, were optimized and in agreement with the experimental data we note that $\mathbf{8 a}$ is more stable than its corresponding isomer by $10.6 \mathrm{KJ} / \mathrm{mol}$ considering only the optimization energy. Following the frequency analysis, we evaluated the $\mathrm{ZPE}$ corrected $\Delta \mathrm{H}$ and $\Delta \mathrm{G}$, these values confirm that $8 \mathrm{a}$ is more stable by 10.86 and $10.06 \mathrm{KJ} / \mathrm{mol}$, respectively.

A closer look at the optimized geometries verified that $\mathbf{8 a}$ is less sterically strained even if the $\mathrm{PPh}_{3}$ is in cis position to the OMe substituent of the bpy, which could seem counterintuitive in terms of the "classical" Tolman cone angle. The phenyl rings of the $\mathrm{PPh}_{3}$ can rotate to accommodate the OMe substituent between them, thus leading to an overall decrease in geometrical strain.

The sum of the internal angles of the metallacycle in $8 \mathbf{a}$ is $538.02^{\circ}$, closer to the theoretical $540^{\circ}$ for a regular pentagon than 8a-iso, which shows, for the same parameter, $534.46^{\circ}$. The angle between the best planes calculated through the metallacycle $\left(\mathrm{Pt}-\mathrm{N}_{1}-\mathrm{C}_{2}-\mathrm{C}_{2^{\prime}}-\mathrm{N}_{1^{\prime}}\right)$ and the one through the coordination plane (Pt-P-C- $\mathrm{N}_{1}-\mathrm{N}_{1^{\prime}}$ ) is very similar for both isomers but lower for $8 \mathbf{a}, 12.04 \mathrm{vs}$. 12.80 . It is interesting to observe that the two pyridine rings are bent 12 degrees from the metallacycle plane in 8 a-iso while only $7.6^{\circ}$ in 8 .

DFT data suggest that the lower stability of 8a-iso is due to a mixture of steric and electronic factors: the less flexible methyl group cis to the OMe substituent of the bpy ${ }^{6 \mathrm{OMe}}$ creates a greater distortion in the structure and, being the group with the highest trans-influence in the coordination sphere, is positioned trans to the pyridinic nitrogen which has a stronger trans-influence compared to the one of the substituted ring. 
In the case of $8 \mathbf{a}$, the $\mathrm{PPh}_{3}$ accommodates the OMe substituent better and the methyl group places itself in trans to the group that has the lowest trans-influence, in agreement with the trans-influence rule in square planar $\mathrm{Pt}(\mathrm{II})$ complexes.

Furthermore, it should also be noted that complex 8a needs an isomerization to be formed, having the unsubstituted pyridine ring in cis to the coordinated methyl group, whereas the starting complex 6a has a cis $\mathrm{PPh}_{3}$-unsubstituted pyridine configuration.

As a conclusion, $\mathrm{PPh}_{3}$ is usually considered a bulky ligand, having a $145^{\circ}$ cone angle, on the basis of this value isomer 8a-iso is expected to be the stable isomer. However, as shown by the optimized geometry of 8a, reported in Figure 8, the cone angle should not be considered as a "solid cone" but in some cases can make room inside to host a substituent. This result is interesting and can lead to a revisitation of ligand "bulkiness" and "cone angle" concepts.

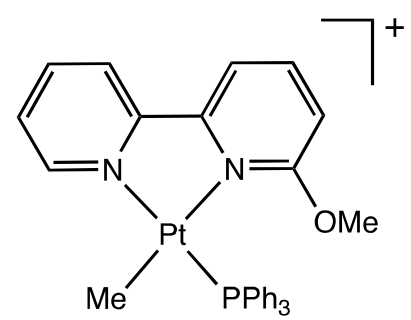

$\mathbf{8 a}$

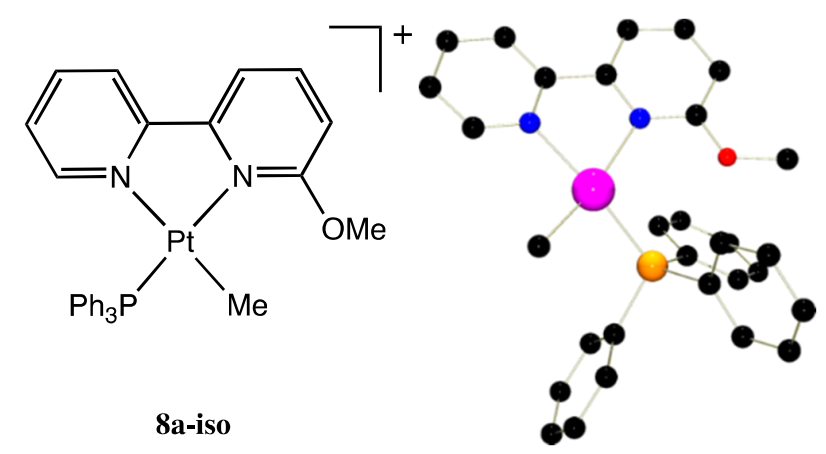

8a-iso

Figure 8. On the left: compounds 8a and 8a-iso; on the right: optimized geometry of $8 \mathbf{a}$ (hydrogens were omitted for clarity).

When the reaction is performed on the second complex, $6 \mathbf{b},\left[\mathrm{Pt}\left(\mathrm{bpy}^{6 \mathrm{Et}}-\mathrm{H}\right)(\mathrm{Me})\left(\mathrm{PPh}_{3}\right)\right]$, the results are, also in this case, different. In this case the nitrogen is easily protonated to give the mesoionic cationic complex $\left[\mathrm{Pt}\left(\mathrm{bpy}{ }^{6 \mathrm{Et} *}\right)(\mathrm{Me})\left(\mathrm{PPh}_{3}\right)\right]\left[\mathrm{BF}_{4}\right], \mathbf{9 b}-\mathrm{BF}_{4}$, with high yields. Also in this case, the NMR spectra confirm the proposed formulation; in particular, the NH proton appears as a broad singlet at 13.2 and the ${ }^{31} \mathrm{P}$ NMR spectrum is in agreement with a P-Pt-C trans coordination $(\delta=31.2 \mathrm{ppm}$; $\left.\mathrm{J}_{\mathrm{Pt}-\mathrm{P}}=2400 \mathrm{~Hz}\right)$. Comparison with the parent complex $6 \mathbf{b}\left(\delta=32,7 \mathrm{ppm}, \mathrm{J}_{\mathrm{Pt}-\mathrm{P}}=2221 \mathrm{~Hz}\right)$ show an increase in the Pt-P coupling constant, indicative of a stronger Pt-P bond. The diagnostic $\mathrm{H}_{4}$ and $\mathrm{H}_{3^{\prime}}$ protons, as expected, are strongly deshielded with respect to the parent complex $6 \mathbf{b}: \mathrm{H}_{4} \delta=0.79 \mathrm{ppm}$, $\mathrm{H}_{3^{\prime}}, \delta=0.39 \mathrm{ppm}$ ).

Interestingly, complex $9 \mathrm{~b}$ is fairly stable in solution not giving signs of retro-rollover conversion, whereas the analogous complex $\left[\mathrm{Pt}\left(\text { pyqui }{ }^{*}\right)(\mathrm{Me})\left(\mathrm{PPh}_{3}\right)\right]^{+}$in 2 days completely converts in its $\kappa^{2}-\mathrm{N}, \mathrm{N}$ isomer.

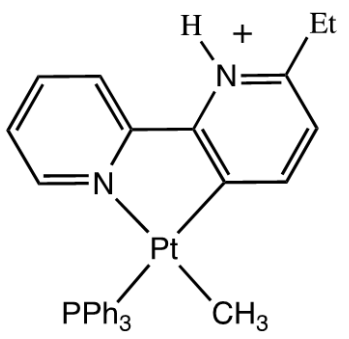

$9 \mathbf{b}$

The reaction with the adduct $\mathrm{H}_{3} \mathrm{O}^{+}$-crown ether was finally studied also in the case of complexes $7 \mathbf{a}$ and $\mathbf{7 b},\left[\mathrm{Pt}\left(\mathrm{bpy}^{6 \mathrm{OMe}}-\mathrm{H}\right)(\mathrm{Cl})\left(\mathrm{PPh}_{3}\right)\right]$ and $\left[\mathrm{Pt}\left(\mathrm{bpy}^{6 \mathrm{Et}}-\mathrm{H}\right)(\mathrm{Cl})\left(\mathrm{PPh}_{3}\right)\right]$. Even in this case, the behavior of the two complexes is different; complex 7 a does not react with the acid, likely due to the scarce basicity 
of the free nitrogen atom and the platinum atom. The Pt-C $\left(\mathrm{sp}^{2}\right)$ bond is stable under the reaction conditions studied and complex $\mathbf{7 a}$ is recovered unreacted. In contrast, the free nitrogen in complex $\mathbf{7 b}$ is rapidly protonated to give the cationic complex $\left[\mathrm{Pt}\left(\mathrm{bpy}^{6 \mathrm{Et} *}\right)(\mathrm{Cl})\left(\mathrm{PPh}_{3}\right)\right]^{+}, \mathbf{1 0 b}\left({ }^{1} \mathrm{H} \mathrm{NMR}: \delta 13.3 \mathrm{ppm}\right.$, broad). As expected, after protonation the $\mathrm{H}_{4}$ and $\mathrm{H}_{3^{\prime}}$ signals appear deshielded by ca 0.8 and $0.5 \mathrm{ppm}$, respectively. In addition, the ${ }^{31} \mathrm{P}$ NMR signal moves from 22.61 to $19.59 \mathrm{ppm}$, with a reduction of the ${ }^{195} \mathrm{Pt}^{31} \mathrm{P}$ coupling constant value (from 4297 to $4139 \mathrm{~Hz}$ ). The complex is stable both in solution and in the solid state.

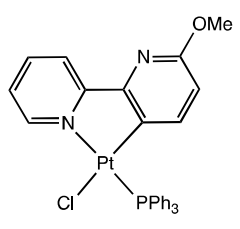

$\left.\left[\mathrm{H}_{3} \mathrm{O} \cdot 18-c r 0 w n-6\right] \mathrm{BF}\right]$ $\underset{\text { acetone, r.t. }}{\stackrel{\text { no reaction }}{\longrightarrow}}$

$7 a$

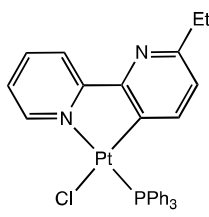

$7 b$

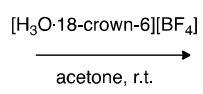

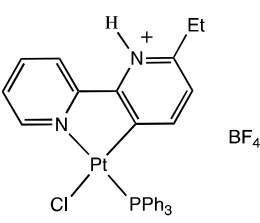

$10 \mathrm{~b}$

In general, all the $\mathrm{bpy}^{6 \mathrm{Et}}$ rollover complexes were easily protonated by reaction with $\left[\mathrm{H}_{3} \mathrm{O} \cdot 18\right.$-crown-6] $\left[\mathrm{BF}_{4}\right]$, whereas none of the bpy ${ }^{6 \mathrm{OMe}}$ complexes show any trace of protonation, with the possible exception of complex $6 \mathbf{a}$, which, follows a rapid retro-rollover reaction. With the intention to shed light into this behavior, we analyzed by means of DFT calculations complexes $\mathbf{1 a}-\mathbf{b}$, $\mathbf{4 a}-\mathbf{b}, \mathbf{6 a}-\mathbf{b}, \mathbf{7 a}-\mathbf{b}$ and their nitrogen-protonated counterparts $3 \mathbf{a}-\mathbf{b}, \mathbf{5 a}-\mathbf{b}, \mathbf{9 a}-\mathbf{b}, \mathbf{1 0 a}-\mathbf{b}$ (obtained bpy ${ }^{6 \mathrm{Et}}$ and not obtained bpy ${ }^{6 \mathrm{OMe}}$ ) (see Supplementary Materials). In addition, as a comparison, the analogous unsubstituted 2,2'-bpy complexes 1e, 4e, 6e, 7e, 3e, 5e, 9e, 10e, were analyzed as well (see Scheme 2).

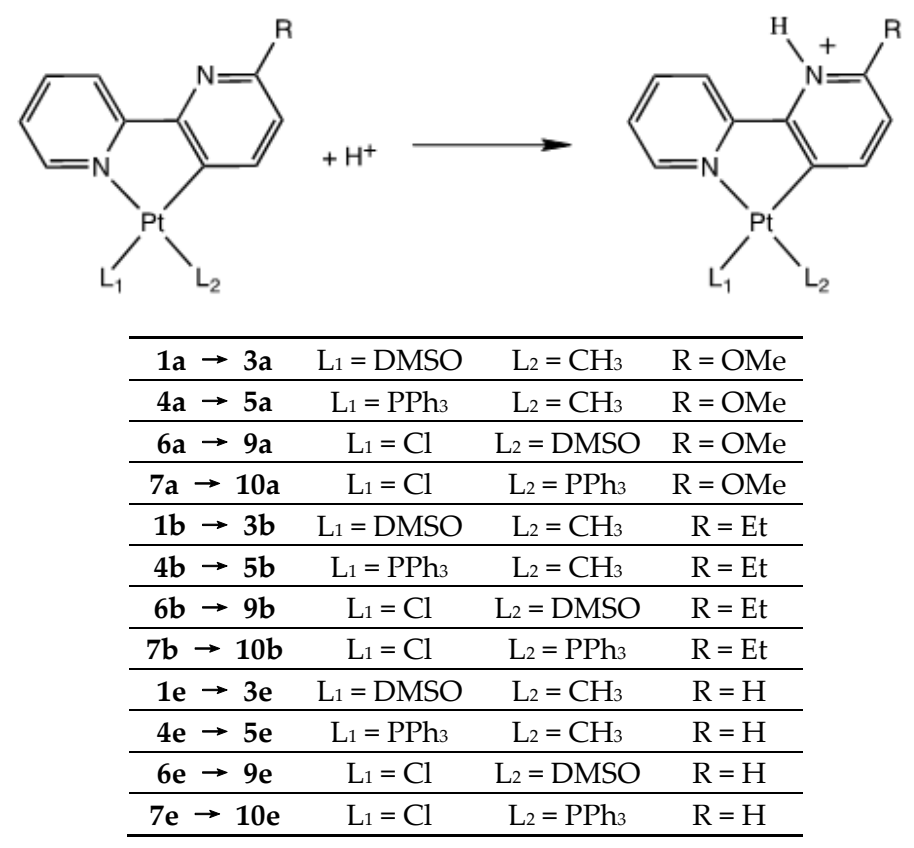

Scheme 2. Rollover neutral and protonated complexes analyzed by means of DFT calculations. 
Proton affinity values (P.A.) were calculated as the reverse enthalpy changes of the reaction reported in Scheme 2, according to ref [81].

It is worth noting that free 2,2'-bipyridines adopt the more stable $\mathrm{N}, \mathrm{N}$ transoid coplanar conformation [82] (Chart 1, B) found in rollover cyclometalated complexes, in place of the less stable cisoid coplanar configuration (Chart 1, A), adopted in chelated complexes.

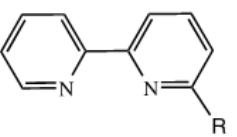

A (cis-bpy)

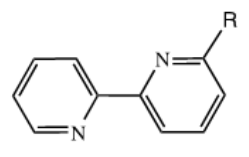

B (trans-bpy)

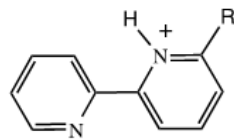

C (trans-bpyH)

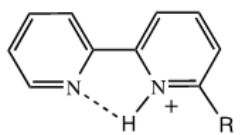

D (cis-bpyH)

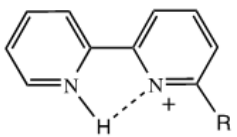

E (cis-bpyH unsub)

Chart 1. Cisoid and transoid conformations of neutral and protonated 6-substituted-2,2'-bipyridines.

In order to compare similar conformations in free ligands and rollover complexes, we comment here only P.A. data for the transoid neutral and protonated species (Chart $1 \mathrm{~B} \rightarrow \mathrm{C}$; Table 4, first line of data). In the protonated ligands, however, the cisoid configuration (D or E) is the most stable one, due to the presence of a weak $\mathrm{N}-\mathrm{H}-\mathrm{N}$ interaction $(\mathrm{N}-\mathrm{H}$ distances 1.96-1.98 $\mathrm{A}$ ). Table 4 (second line of data) also reports true P.A. data, i.e., those relative to the stable species $\mathrm{D}$ (bpy ${ }^{6 \mathrm{Et}}$ ) or $\mathrm{E}\left(\mathrm{bpy}^{6 \mathrm{OMe}}\right.$ ).

Table 4. DFT calculated proton affinity data (P.A., $\mathrm{KJ} / \mathrm{mol}$ ) for uncoordinated ligands and related complexes.

\begin{tabular}{cccccc}
\hline & Neutral/Protonated & Ancillary Ligands & Bpy $^{\mathbf{6 o m e}}$ & Bpy $^{\text {6et }}$ & Bpy \\
\hline \multirow{2}{*}{ Free ligands } & $\mathrm{bpy}^{\mathrm{R}}-\mathrm{bpy}^{\mathrm{R}} \mathrm{H}^{+(\mathrm{a})} \mathrm{B} \rightarrow \mathrm{C}$ & & 952.22 & 968.30 & 948.51 \\
& $\mathrm{bpy}^{\mathrm{R}}-\mathrm{bpy}^{\mathrm{R}} \mathrm{H}^{+(\mathrm{b})} \mathrm{B} \rightarrow \mathrm{D}(\mathrm{E})$ & & $985.05(\mathrm{E})(\mathrm{c})$ & 1002.76 & 982.72 \\
& $1-3$ & $\mathrm{Me} / \mathrm{DMSO}$ & 970.85 & 1005.23 & 990.15 \\
\multirow{5}{*}{ complexes } & $4-5$ & $\mathrm{Cl} / \mathrm{DMSO}$ & 954.78 & 988.48 & 972.45 \\
& $6-9$ & $\mathrm{Me} / \mathrm{PPh}_{3}$ & 992.85 & 1027.63 & 1014.17 \\
& $7-10$ & $\mathrm{Cl} / \mathrm{PPh}_{3}$ & 972.22 & 1006.37 & 992.51 \\
\hline
\end{tabular}

(a) transoid coplanar configuration for protonated bipyridines; (b) cisoid coplanar configuration for protonated bipyridines. (c) in this case, the most stable species (E) is protonated on the unsubstituted pyridine-nitrogen. The P.A. value for species $\mathrm{D}$ is $983.96 \mathrm{KJ} / \mathrm{mol}$.

P.A. data limited to transoid conformations (Chart $1, \mathrm{~B} \rightarrow \mathrm{C}$ ) reported in Table 4, show that bpy ${ }^{6 \mathrm{Et}}$ complexes have systematically higher values (ca $34-35 \mathrm{KJ} / \mathrm{mol}$ ) than corresponding bpy ${ }^{6 \mathrm{OMe}}$ ones. Unsubstituted bipyridine complexes (1e-10e) lie in the middle. In contrast, when the free ligands are considered, 2,2'-bipyridine has a lower P.A. value $(948.5 \mathrm{KJ} / \mathrm{mol})$ than free bpy ${ }^{6 \mathrm{OMe}}(952.4 \mathrm{KJ} / \mathrm{mol})$, even considering the cisoid conformations ( $982.7 \mathrm{vs} .985 .0 \mathrm{KJ} / \mathrm{mol})$.

Taking into account only transoid conformations, in the ligands the higher P.A. value is shown, as expected, by uncoordinated bpy ${ }^{6 \mathrm{Et}}(968.3 \mathrm{KJ} / \mathrm{mol})$, only $16 \mathrm{KJ} / \mathrm{mol}$ above bpy ${ }^{6 \mathrm{OMe}}$ and less than half of the difference found in corresponding complexes. On the whole, all complexes have higher P.A. values than free ligands, with only complex $5 \mathbf{a}$, close to the free ligand.

In contrast, the cisoid conformations of protonated free ligands (D, E) show a remarkable additional stability likely due to the above-mentioned $\mathrm{N}-\mathrm{H}-\mathrm{N}$ interaction. It is worth noting that protonation of free $\mathrm{bpy}^{6 \mathrm{OMe}}$ affords isomer $\mathrm{E}$ as the most stable species, resulting in protonation of the nitrogen of the unsubstituted pyridine ring. It results, on the whole, that the methoxy substituent seems to have a subtle effect on the donor properties of the adjacent nitrogen atom, which effects the overall behavior of bpy ${ }^{6 \mathrm{OMe}}$ both as a free ligand and in its complexes.

Extrapolation of these data suggests that while free bpy ${ }^{6 \mathrm{OMe}}$ is more basic than bpy, its rollover complexes are less basic; as a consequence, experimentally, its rollover complexes do not show signs of nitrogen protonation. 
On the whole, this study shows, as expected, that higher P.A. values are found with better donor ligands (compounds 6 b/9b, P.A. $=1027.6 \mathrm{KJ} / \mathrm{mol}$; ancillary ligands: $\mathrm{PPh}_{3}$, Me; substituent: 6-ethyl), whereas the lower values are found in connection with worst donors (compounds $\mathbf{4 a} / \mathbf{5 a}$ P.A. $=954.8 \mathrm{KJ} / \mathrm{mol} \mathrm{KJ} / \mathrm{mol}$; ancillary ligands: DMSO, Cl; substituent: 6-methoxy).

\section{Conclusions}

The behavior of cyclometalated rollover complexes reflects a delicate balance of different contribution from the metal, the ancillary ligands, and the rollover cyclometalated bipyridine. In particular, the nature of the substituent in 6-substituted-2,2'-bipyridines affects not only their behavior towards $\mathrm{C}(3)-\mathrm{H}$ bond activation, but also the reactivity of the resulting rollover complexes.

All these considerations are also valid for classic cyclometalated complexes; in addition, "rollover" deprotonated ligands have the peculiarity of being no more a spectator in the reactivity of the complex but may act as a "ligand with multiple personalities" due to the presence of the uncoordinated nitrogen.

As a consequence of the behavior of $\mathrm{Pt}$ (II) cyclometalated rollover complexes with 6-ethyl-2,2'-bipyridine (bpy ${ }^{6 \mathrm{Et}}$ ) and 6-methoxy-2,2'-bipyridine (bpy ${ }^{6 \mathrm{OMe}}$ ), two ligands with similar steric hindrance but different electronic properties, is very different.

In particular, the new complexes react in very different ways towards protonation: in addition to differences given by substituents and ancillary ligands, the reaction is complicated by the presence of several nucleophilic centers in the complexes.

Experiments showed that all the bpy ${ }^{6 \mathrm{Et}}$ rollover complexes can be easily protonated by

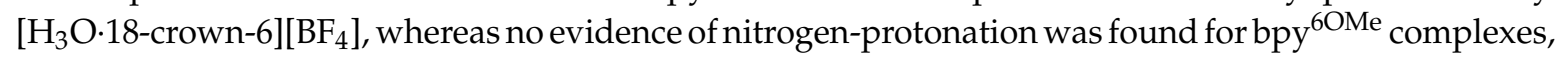
with the possible exception of complex $\mathbf{6 a}$.

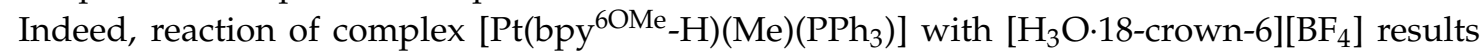
in a retro-rollover reaction whose final product is the cationic adduct $\left[\mathrm{Pt}\left(\mathrm{bpy}{ }^{\mathrm{OMe}}\right)(\mathrm{Me})\left(\mathrm{PPh}_{3}\right)\right]^{+}$. Surprisingly, only the isomer with the cis- $\mathrm{PPh}_{3}-\mathrm{OMe}$ geometry is formed, in spite of an expected instability due to steric hindrance of the $\mathrm{PPh}_{3}$ ligand (cone angle $145^{\circ}$ ). Surprisingly, the $\mathrm{OMe}$ substituent is situated in the neighborhood of the phenyl rings of the bulky $\mathrm{PPh}_{3}$ rather than close to the much smaller methyl ligand. This result reminds us that too often the cone angle is considered as a real "solid cone", which is not always true. This result is interesting and may elicit a reflection on the use and interpretation of the cone angle concept.

Supplementary Materials: The following are available online at http://www.mdpi.com/2076-3417/10/19/6665/s1, DFT-based coordinates for the equilibrium geometry for compounds 8a, 8a-iso; 1a, 1b, 1e; 3a, 3b, 3e; 4a, 4b, $4 e ; 5 a, 5 b, 5 e ; 6 a, 6 b, 6 e ; 7 a, 7 b, 7 e ; 9 a, 9 b, 9 e ; 10 a, 10 b, 10 e$. Scheme for the protonation reactions. Table S1: Coordinates for the equilibrium geometry for 8a-iso; Table S2: Coordinates for the equilibrium geometry for 8a; Table S3: Selected bond distances, in $\AA$, for 8a and 8a-iso; Table S4: Selected angles, in degrees, for 8a and 8a-iso; Table S5: Coordinates for the equilibrium geometry for 1a; Table S6: Coordinates for the equilibrium geometry for 3a; Table S7: Coordinates for the equilibrium geometry for 4a; Table S8: Coordinates for the equilibrium geometry for 5a; Table S8: Coordinates for the equilibrium geometry for 5a; Table S10: Coordinates for the equilibrium geometry for 9a; Table S11: Coordinates for the equilibrium geometry for 7a; Table S12: Coordinates for the equilibrium geometry for 10a; Table S13: Coordinates for the equilibrium geometry for 1b; Table S14: Coordinates for the equilibrium geometry for 3b; Table S15: Coordinates for the equilibrium geometry for $4 b$; Table S16: Coordinates for the equilibrium geometry for 5b; Table S17: Coordinates for the equilibrium geometry for 6b; Table S18: Coordinates for the equilibrium geometry for 9b; Table S19: Coordinates for the equilibrium geometry for 7b; Table S20: Coordinates for the equilibrium geometry for 10b; Table S21: Coordinates for the equilibrium geometry for 1e; Table S22: Coordinates for the equilibrium geometry for 3e; Table S23: Coordinates for the equilibrium geometry for 4e; Table S24: Coordinates for the equilibrium geometry for 5e; Table S25: Coordinates for the equilibrium geometry for 6e; Table S26: Coordinates for the equilibrium geometry for 9e; Table S27: Coordinates for the equilibrium geometry for 7e; Table S28: Coordinates for the equilibrium geometry for 10e; Figure S1: Optimized geometry of 8a-iso, Figure S2: Optimized geometry of 8a; Figure S5: Optimized geometry of 1a; Figure S6: Optimized geometry of 3a; Figure S7: Optimized geometry of 4a; Figure S8: Optimized geometry of 5a; Figure S9: Optimized geometry of 6a; Figure S10: Optimized geometry of 9a; Figure S11: Optimized geometry of 7a; Figure S12: Optimized geometry of 10a; Figure S13: Optimized geometry of 1b; Figure S14: Optimized geometry of $3 b$; Figure S15: Optimized geometry of $4 b$; Figure S16: Optimized geometry of 5b; Figure S17 Optimized geometry of $\mathbf{6 b}$; Figure S18: Optimized geometry of 9b; Figure S19: Optimized geometry of 7b; Figure S20: Optimized geometry of 10b; Figure S21: Optimized geometry of 1e; Figure S22: Optimized geometry of 3e; Figure S23: Optimized geometry of 4e; Figure S24: Optimized geometry of 5e; Figure S25: Optimized 
geometry of 6e; Figure S26: Optimized geometry of 9e; Figure S27: Optimized geometry of 7e; Figure S28: Optimized geometry of 10e;

Author Contributions: Conceptualization, A.Z.; Formal analysis, A.Z., L.M., M.I.P., S.P., M.S. and S.S.; Funding acquisition, A.Z., M.I.P. and S.S.; Investigation, A.Z., L.M., M.I.P., S.P. and M.S.; Methodology, A.Z., L.M. and M.I.P.; Resources, A.Z., M.I.P. and S.S.; Software, L.M.; Supervision, A.Z.; Writing-original draft, A.Z., L.M., M.I.P., S.P. and M.S.; Writing-review \& editing, A.Z., L.M., M.I.P., S.P. and S.S. All authors have read and agreed to the published version of the manuscript.

Funding: This research was funded by Università degli Studi di Sassari (“Fondo di Ateneo per la ricerca 2019") and Regione Autonoma della Sardegna (grant CRP-78365 "Complessi di Au e Pt derivanti da donatori calcogeni e pnicogeni: applicazione quali antimicrobici", L.R. 7 agosto 2007 n. 7, annualità 2013).

Acknowledgments: Financial support from Università degli Studi di Sassari is gratefully acknowledged ("Fondo di Ateneo per la ricerca 2019": AZ, MIP and SS). Regione Autonoma della Sardegna is gratefully acknowledged for the financial support grant CRP-78365 “Complessi di Au e Pt derivanti da donatori calcogeni e pnicogeni: applicazione quali antimicrobici", L.R. 7 agosto 2007 n. 7, annualità 2013 (AZ and SP).

Conflicts of Interest: The authors declare no conflict of interest. The funders had no role in the design of the study; in the collection, analyses, or interpretation of data; in the writing of the manuscript, or in the decision to publish the results.

\section{References}

1. Albrecht, M. Cyclometalation using d-block transition metals: Fundamental aspects and recent trends. Chem. Rev. 2010, 110, 576-623. [CrossRef] [PubMed]

2. Crespo, M. Diarylplatinum(II) Compounds as Versatile Metallating Agents in the Synthesis of Cyclometallated Platinum Compounds with N-Donor Ligands. Inorganics 2014, 2, 115-131. [CrossRef]

3. Crespo, M.; Martínez, M.; Nabavizadeh, S.M.; Rashidi, M. Kinetico-mechanistic studies on C-X (X = H, F, $\mathrm{Cl}, \mathrm{Br}, \mathrm{I})$ bond activation reactions on organoplatinum(II) complexes. Coord. Chem. Rev. 2014, 279, 115-140. [CrossRef]

4. Butschke, B.; Schwarz, H. "Rollover" cyclometalation-Early history, recent developments, mechanistic insights and application aspects. Chem. Sci. 2012, 3, 308-326. [CrossRef]

5. Zucca, A.; Petretto, G.L.; Stoccoro, S.; Cinellu, M.A.; Manassero, M.; Manassero, C.; Minghetti, G. Cyclometallation of 2,2'-bipyridine. Mono and Dinuclear C,N Platinum(II) derivatives. Organometallics 2009, 28, 2150-2159. [CrossRef]

6. Aghakhanpour, R.B.; Rashidi, M.; Hosseini, F.N.; Raoofa, F.; Nabavizadeh, S.M. Oxidation of a rollover cycloplatinated(ii) dimer by MeI: A kinetic study. RSC Adv. 2015, 5, 66534-66542. [CrossRef]

7. Skapski, A.C.; Sutcliffe, V.F.; Young, G.B. 'Roll-over' 3-Metallation of Co-ordinated 2,2'-Bipyridyl in the Thermal Rearrangement of Diaryl(bipyridyl)platinum(II) Complexes: Molecular Structure of (m-bidyl)[PtPh(Bu $\left.\left.{ }^{\mathrm{t} p y}\right)\right]_{2}$. J. Chem. Soc. Chem. Commun. 1985, 609-611. [CrossRef]

8. Minghetti, G.; Stoccoro, S.; Cinellu, M.A.; Soro, B.; Zucca, A. Activation of a C-H Bond in a Pyridine Ring. Reaction of 6-substituted 2,2'-bipyridines with Methyl and Phenyl Platinum(II) Derivatives: $\mathrm{N}^{\prime}, \mathrm{C}(3)-“$ Rollover" Cyclometallation. Organometallics 2003, 22, 4770-4777. [CrossRef]

9. Yang, W.; Chen, J.; Huang, X.; Ding, J.; Liu, M.; Wu, H. Pd-catalyzed intramolecular aerobic oxidative C-H amination of 2-aryl-3-(arylamino)quinazolinones: Synthesis of fluorescent indazolo[3,2-b]quinazolinones. Org. Lett. 2014, 16, 5418-5421. [CrossRef]

10. Shibata, T.; Takayasu, S. Synthesis of Multicyclic Heterocycles Initiated by C-H Bond Activation Along with "Rollover" Using a Rh(III) Catalyst. Heteroatom Chem. 2014, 25, 379-388. [CrossRef]

11. Yu, S.; Li, X. Mild Synthesis of Chalcones via Rhodium(III)-Catalyzed C-C Coupling of Arenes and Cyclopropenones. Org. Lett. 2014, 16, 1220-1223. [CrossRef] [PubMed]

12. Kwak, J.; Ohk, Y.; Jung, Y.; Chang, S. Rollover Cyclometalation Pathway in Rhodium Catalysis: Dramatic NHC Effects in the C-H Bond Functionalization. J. Am. Chem. Soc. 2012, 134, 17778-17788. [CrossRef] [PubMed]

13. Ghoochany, L.T.; Kerner, C.; Farsadpour, S.; Menges, F.; Sun, Y.; Niedner-Schatteburg, G.; Thiel, W.R. C-H Activation at a Ruthenium(II) Complex-The Key Step for a Base-Free Catalytic Transfer Hydrogenation? Eur. J. Inorg. Chem. 2013, 24, 4305-4317. [CrossRef]

14. Ghorai, D.; Dutta, C.; Choudhury, J. Switching of "rollover Pathway" in Rhodium(III)-Catalyzed C-H Activation of Chelating Molecules. ACS Catal. 2016, 6, 709-713. [CrossRef] 
15. Zucker, S.P.; Wossidlo, F.; Weber, M.; Lentz, D.; Tzschucke, C.C. Palladium-Catalyzed Directed Halogenation of Bipyridine N-Oxide. J. Org. Chem. 2017, 82, 5616-5635. [CrossRef] [PubMed]

16. Li, J.; Yang, Y.; Wang, Z.; Feng, B.; You, J. Rhodium(III)-Catalyzed Annulation of Pyridinones with Alkynes via Double C-H Activation: A Route to Functionalized Quinolizinones. J. Org. Lett. 2017, 19, 3083-3086. [CrossRef] [PubMed]

17. Yu, J.; Wen, S.; Ba, D.; Lv, W.; Chen, Y.; Cheng, G. Rhodium(III)-Catalyzed Regioselective C3-H Acylmethylation of [2,2'-Bipyridine]-6-carboxamides with Sulfoxonium Ylides. Org. Lett. 2019, 21, 6366-6369. [CrossRef]

18. Dutta, C.; Ghorai, D.; Choudhury, J. To “Rollover” or Not? Stereoelectronically Guided C-H Functionalization Pathways from Rhodium-Abnormal NHC Intermediates. ACS Omega 2018, 3, 1614-1620. [CrossRef] [PubMed]

19. Yu, J.; Lv, W.; Cheng, G. Palladium-Catalyzed Site-Selective C-H Arylation of 2,2'-Bipyridine-6-carboxamides via a Rollover Cyclometalation Pathway. Org. Lett. 2018, 20, 4732-4735. [CrossRef]

20. Crabtree, R.H. Creating ligands with multiple personalities. Science 2010, 330, 455-456. [CrossRef]

21. Crabtree, R.H. Abnormal, mesoionic and remote N-heterocyclic carbene complexes. Coord. Chem. Rev. 2013, 257, 755-766. [CrossRef]

22. Iglesias, M.; Albrecht, M. Expanding the family of mesoionic complexes: Donor properties and catalytic impact of palladated isoxazolylidenes. Dalton Trans. 2010, 39, 5213-5215. [CrossRef] [PubMed]

23. Maidich, L.; Zuri, G.; Stoccoro, S.; Cinellu, M.A.; Masia, M.; Zucca, A. Mesoionic complexes of platinum(II) derived from "rollover" cyclometalation: A delicate balance between $\mathrm{Pt}-\mathrm{C}(\mathrm{sp} 3)$ and $\mathrm{Pt}-\mathrm{C}(\mathrm{sp} 2)$ bond cleavage as a result of different reaction conditions. Organometallics 2013, 32, 438-448. [CrossRef]

24. Schuster, O.; Yang, L.; Raubenheimer, H.G.; Albrecht, M. Beyond Conventional N-Heterocyclic Carbenes: Abnormal, Remote, and Other Classes of NHC Ligands with Reduced Heteroatom Stabilization Beyond Conventional N-Heterocyclic Carbenes: Abnormal, Remote, and Other Classes of NHC Ligands with Reduced Hetero. Chem. Rev. 2009, 109, 3445-3478. [CrossRef]

25. Vivancos, Á.; Segarra, C.; Albrecht, M. Mesoionic and Related Less Heteroatom-Stabilized N-Heterocyclic Carbene Complexes: Synthesis, Catalysis, and Other Applications. Chem. Rev. 2018, 118, 9493-9586. [CrossRef] [PubMed]

26. Leist, M.; Kerner, C.; Ghoochany, L.T.; Farsadpour, S.; Fizia, A.; Neu, J.P.; Schön, F.; Sun, Y.; Oelkers, B.; Lang, J.; et al. Roll-over cyclometalation: A versatile tool to enhance the catalytic activity of transition metal complexes. J. Organomet. Chem. 2018, 863, 30-43. [CrossRef]

27. Omae, I. Unconventional Cyclometalation Reactions. Curr. Org. Chem. 2014, 18, 2776-2795. [CrossRef]

28. Maidich, L.; Zucca, A.; Clarkson, G.J.; Rourke, J.P. Oxidative addition of MeI to a rollover complex of Pt(II): Isolation of the kinetic product. Organometallics 2013, 32, 3371-3375. [CrossRef]

29. Maidich, L.; Zuri, G.; Stoccoro, S.; Cinellu, M.A.; Zucca, A. Assembly of symmetrical and unsymmetrical platinum(II) rollover complexes with bidentate phosphine ligands. Dalton Trans. 2014, 43, 14806-14815. [CrossRef]

30. Minghetti, G.; Stoccoro, S.; Cinellu, M.A.; Petretto, G.L.; Zucca, A. “Rollover" Cyclometalated Platinum (II) Hydrides: Mono- and Polynuclear Derivatives. Organometallics 2008, 27, 3415-3421. [CrossRef]

31. Hosseini, F.N.; Nabavizadeh, S.M.; Abu-omar, M.M. Which is the Stronger Nucleophile, Platinum or Nitrogen in Rollover Cycloplatinated(II) Complexes? Inorg. Chem. 2017, 56, 14706-14713. [CrossRef] [PubMed]

32. Petretto, G.L.; Zucca, A.; Stoccoro, S.; Cinellu, M.A.; Minghetti, G. Step by step palladium mediated syntheses of new 2-(pyridin-2-yl)-6-R-nicotinic acids and esters. J. Organomet. Chem. 2010, 695, 256-259. [CrossRef]

33. Zucca, A.; Maidich, L.; Canu, L.; Petretto, G.L.; Stoccoro, S.; Cinellu, M.A.; Clarkson, G.J.; Rourke, J.P. Rollover-assisted $\mathrm{C}\left(\mathrm{sp}^{2}\right)-\mathrm{C}\left(\mathrm{sp}^{3}\right)$ bond formation. Chem. A Eur. J. 2014, 20, 5501-5510. [CrossRef] [PubMed]

34. Hong, S.Y.; Kwak, J.; Chang, S. Rhodium-catalyzed selective C-H functionalization of NNN tridentate chelating compounds via a rollover pathway. Chem. Commun. 2016, 52, 3159-3162. [CrossRef]

35. Jongbloed, L.S.; De Bruin, B.; Reek, J.N.H.; Lutz, M.; Van Der Vlugt, J.I. Reversible cyclometalation at $\mathrm{Rh}^{\mathrm{I}}$ as a motif for metal-ligand bifunctional bond activation and base-free formic acid dehydrogenation. Catal. Sci. Technol. 2016, 6, 1320-1327. [CrossRef]

36. Alam, P.; Kaur, G.; Chakraborty, S.; Roy Choudhury, A.; Laskar, I.R. Aggregation induced phosphorescence active rollover iridium(III) complex as a multi-stimuli-responsive luminescence material. Dalton Trans. 2015, 44, 6581-6592. [CrossRef] 
37. Paziresh, S.; Babadi Aghakhanpour, R.; Rashidi, M.; Nabavizadeh, S.M. Simple tuning of the luminescence properties of the double rollover cycloplatinated(II) structure by halide ligands. New J. Chem. 2018, 42, 1337-1346. [CrossRef]

38. Aghakhanpour, R.B.; Nabavizadeh, S.M.; Rashidi, M. Newly designed luminescent di- and tetra-nuclear double rollover cycloplatinated(II) complexes. J. Organomet. Chem. 2016, 819, 216-227. [CrossRef]

39. Abedi, A.; Amani, V.; Safari, N.; Ostad, S.N.; Notash, B. From proton transferred to cyclometalated platinum(IV) complex: Crystal structure and biological activity. J. Organomet. Chem. 2015, 799-800, 30-37. [CrossRef]

40. Fereidoonnezhad, M.; Shahsavari, H.R.; Abedanzadeh, S.; Behchenari, B.; Hossein-Abadi, M.; Faghih, Z.; Hassan Beyzavi, M. Cycloplatinated(II) complexes bearing 1,1'-bis(diphenylphosphino)ferrocene ligand: Biological evaluation and molecular docking studies. New J. Chem. 2018, 42, 2385-2392. [CrossRef]

41. Akbarzadeh, S.; Ebrahimi, F.; Faghih, Z.; Movahed Zahra, F.A. Cytotoxic Effect Two Novel Platinum Breast Cancer: An in vitro Study. Asian Pac. J. Cancer Biol. 2018, 3, 11-14. [CrossRef]

42. Babak, M.V.; Pfaffeneder-Kmen, M.; Meier-Menches, S.M.; Legina, M.S.; Theiner, S.; Licona, C.; Orvain, C.; Hejl, M.; Hanif, M.; Jakupec, M.A.; et al. Rollover Cyclometalated Bipyridine Platinum Complexes as Potent Anticancer Agents: Impact of the Ancillary Ligands on the Mode of Action. Inorg. Chem. 2018, 57, 2851-2864. [CrossRef] [PubMed]

43. Fereidoonnezhad, M.; Niazi, M.; Shahmohammadi Beni, M.; Mohammadi, S.; Faghih, Z.; Faghih, Z.; Shahsavari, H.R. Synthesis, Biological Evaluation, and Molecular Docking Studies on the DNA Binding Interactions of Platinum(II) Rollover Complexes Containing Phosphorus Donor Ligands. ChemMedChem 2017, 12, 456-465. [CrossRef] [PubMed]

44. Giordano, T.J.; Rasmussen, P.G. Platinum and palladium complexes of thienylpyridine. Compounds containing metal-carbon bonds. Inorg. Chem. 1975, 14, 1628-1634. [CrossRef]

45. Zhao, S.-B.; Wang, R.-Y.; Wang, S. Intramolecular C-H activation directed self-assembly of an organoplatinum(II) molecular square. J. Am. Chem. Soc. 2007, 129, 3092-3093. [CrossRef]

46. Zucca, A.; Cinellu, M.A.; Pinna, M.V.; Stoccoro, S.; Minghetti, G.; Manassero, M.; Sansoni, M. Cyclopalladation of 6-substituted-2,2'-bipyridines. Metallation of unactivated methyl groups vs. aromatic C-H activation. Organometallics 2000, 19, 4295-4304. [CrossRef]

47. Doppiu, A.; Minghetti, G.; Cinellu, M.A.; Stoccoro, S.; Zucca, A.; Manassero, M. Unprecedented Behavior of 2,2':6'-2"-Terpyridine: Dinuclear Platinum(II) Derivatives with a new N,C; C,N Bridging ligand. Organometallics 2001, 20, 1148-1152. [CrossRef]

48. Zucca, A.; Cordeschi, D.; Stoccoro, S.; Cinellu, M.A.; Minghetti, G.; Chelucci, G.; Manassero, M. Platinum(II) cyclometallated "rollover" complexes with a chiral pinene-derived 2,2'-bipyridine. Organometallics 2011, 30 , 3064-3074. [CrossRef]

49. Stoccoro, S.; Maidich, L.; Ruiu, T.; Cinellu, M.A.; Clarkson, G.J.; Zucca, A. Chiral cyclometalation of 6-(1-phenylbenzyl)-2,2'-bipyridine. Dalton Trans. 2015, 44, 18001-18011. [CrossRef]

50. Cocco, F.; Zucca, A.; Stoccoro, S.; Guerri, A.; Serratrice, M.; Cinellu, M.A. Synthesis and Characterization of Palladium(II) and Platinum(II) Adducts and Cyclometalated Complexes of 6,6'-Dimethoxy-2,2'-bipyridine- $\mathrm{C}\left(\mathrm{sp}^{3}\right)-\mathrm{H}$ and $\mathrm{C}\left(\mathrm{sp}^{2}\right)-\mathrm{H}$ Bond Activations. Organometallics 2014, 33, 3414-3424. [CrossRef]

51. Vogel, A.I. Vogel's Textbook of Practical Organic Chemistry, 5th ed.; Longman Scientific and Technical: Harlow, UK, 1989.

52. Eaborn, C.; Kundu, K.; Pidcock, A. Synthesis of platinum(II) alkyl and aryl complexes from $\mathrm{K}_{2}\left[\mathrm{PtCl}_{4}\right]$ and tetraorganotin compounds in dimethyl sulphoxide. J. Chem. Soc. Dalton Trans. 1981, 933-938. [CrossRef]

53. Romeo, R.; Monsu Scolaro, L. (2,2:6,2"-terpyridine)methylplatinum(II) chloride and (1,10-phenanthroline) methylchloroplatinum(II). Inorg. Synth. 1998, 32, 153.

54. Baquero, E.A.; Rodríguez-Zúñiga, A.; Flores, J.C.; Temprado, M.; de Jesús, E. Revisiting the synthesis of trans-[Pt $\left.(\mathrm{dmso})_{2} \mathrm{ClMe}\right]$ and cis- $\left[\mathrm{Pt}(\mathrm{dmso})_{2} \mathrm{Me}_{2}\right]$ : Experimental and DFT studies. J. Organomet. Chem. 2019, 896, 108-112. [CrossRef]

55. Gütz, C.; Lützen, A. Synthesis of 2,2'-Bipyridines via Suzuki-Miyaura Cross-Coupling. Synthesis 2010, 85-90. [CrossRef]

56. Perdew, J.P.; Burke, K.; Ernzerhof, M. Generalized Gradient Approximation Made Simple. Phys. Rev. Lett. 1996, 77, 3865-3868. [CrossRef] [PubMed] 
57. Perdew, J.P.; Burke, K.; Ernzerhof, M. Generalized Gradient Approximation Made Simple. Erratum Phys. Rev. Lett. 1997, 78, 1396. [CrossRef]

58. Adamo, C.; Barone, V. Toward reliable density functional methods without adjustable parameters: The PBE0 model. J. Chem. Phys. 1999, 110, 6158-6170. [CrossRef]

59. van Lenthe, E.; Baerends, E.J.; Snijders, J.G. Relativistic regular two-component Hamiltonians. J. Chem. Phys. 1993, 99, 4597-4610. [CrossRef]

60. Chang, C.; Pelissier, M.; Durand, P. Regular Two-Component Pauli-Like Effective Hamiltonians in Dirac Theory. Phys. Scr. 1986, 34, 394-404. [CrossRef]

61. Heully, J.L.; Lindgren, I.; Lindroth, E.; Lundqvist, S.; Martensson-Pendrill, A.M. Diagonalisation of the Dirac Hamiltonian as a basis for a relativistic many-body procedure. J. Phys. B At. Mol. Phys. 1986, 19, 2799-2815. [CrossRef]

62. van Lenthe, E.; Ehlers, A.; Baerends, E.-J. Geometry optimizations in the zero order regular approximation for relativistic effects. J. Chem. Phys. 1999, 110, 8943-8953. [CrossRef]

63. Pantazis, D.A.; Chen, X.-Y.; Landis, C.R.; Neese, F. All-Electron Scalar Relativistic Basis Sets for Third-Row Transition Metal Atoms. J. Chem. Theory Comput. 2008, 4, 908-919. [CrossRef] [PubMed]

64. Neese, F. The ORCA program system. WIREs Comput. Mol. Sci. 2012, 2, 73-78. [CrossRef]

65. Neese, F. Software update: The ORCA program system, version 4.0. WIREs. Comput. Mol. Sci. 2018, 8, e1327. [CrossRef]

66. Maidich, L.; Cinellu, M.A.; Cocco, F.; Stoccoro, S.; Sedda, M.; Galli, S.; Zucca, A. Platinum(II), palladium(II) and gold(III) adducts and cyclometalated derivatives of 6-methoxy-2,2'-bipyridine: A comparative study. J. Organomet. Chem. 2016, 819, 76-86. [CrossRef]

67. Maidich, L.; Dettori, G.; Stoccoro, S.; Cinellu, M.A.; Rourke, J.P.; Zucca, A. Electronic and steric effects in rollover C-H bond activation. Organometallics 2015, 34, 817-828. [CrossRef]

68. Aue, D.H.; Webb, H.M.; Davidson, W.R.; Toure, P.; Hopkins, H.P.; Moulik, S.P.; Jahagirdar, D.V.; Hopkins, H.P.; Moulik, S.P.; Jahagirdar, D.V. Relationships between the Thermodynamics of Protonation in the Gas and Aqueous Phase for 2-, 3-, and 4-Substituted Pyridines (Proton affinity and basicity data). J. Am. Chem. Soc. 1991, 113, 1770-1780. [CrossRef]

69. pKa Data of Pyridinium Ions, Compiled by Williams, R. Available online: http://research.chem.psu.edu/ brpgroup/pKa_compilation.pdf (accessed on 24 August 2020).

70. Hunter, E.P.L.; Lias, S.G. Evaluated Gas Phase Basicities and Proton Affinities of Molecules: An Update. J. Phys. Chem. Ref. Data 1998, 27, 413-656. [CrossRef]

71. McMurry, J. Organic Chemistry, 8th ed.; Brooks/Cole, Cengage Learning: Belmont, CA, USA, 2012; p. 584.

72. Zucca, A.; Doppiu, A.; Cinellu, M.A.; Minghetti, G.; Stoccoro Manassero, M. Multiple C-H bond activation. 3-fold deprotonated 6-phenyl-2,2'-bipyridine as a bridging ligand in dinuclear platinum(II) derivatives. Organometallics 2002, 21, 783-785. [CrossRef]

73. Zucca, A.; Stoccoro, S.; Cinellu, M.A.; Minghetti, G.; Manassero, M.; Sansoni, M. Metallation of unactivated methyl groups. Platinum(II) derivatives with 6-alkyl-2,2'-bipyridines. Eur. J. Inorg. Chem. 2002, 3336-3346. [CrossRef]

74. Zucca, A.; Maidich, L.; Carta, V.; Petretto, G.L.; Stoccoro, S.; Cinellu, M.A.; Pilo, M.I.; Clarkson, G.J. Cyclometalated Complexes of Platinum(II) with 2-Vinylpyridine. Eur. J. Inorg. Chem. 2014, 2014, 2278-2287. [CrossRef]

75. Chassot, L.; Mueller, E.; von Zelewsky, A. cis-Bis(2-phenylpyridine)platinum(II) (CBPPP): A simple molecular platinum compound. Inorg. Chem. 1984, 23, 4249-4253. [CrossRef]

76. Zucca, A.; Cordeschi, D.; Maidich, L.; Pilo, M.I.; Masolo, E.; Stoccoro, S.; Cinellu, M.A.; Galli, S. Rollover cyclometalation with 2-(2'-pyridyl)quinoline. Inorg. Chem. 2013, 52, 7717-7731. [CrossRef] [PubMed]

77. Hallett, A.J.; Kariuki, B.M.; Pope, S.J.A. New 2,3-disubstituted-5-hydroxyquinoxaline ligands and their coordination chemistry with cyclometallated iridium(III): Syntheses, structures and tunable electronic properties. Dalton Trans. 2011, 40, 9474-9481. [CrossRef]

78. Jamali, S.; Nabavizadeh, S.M.; Rashidi, M. Oxidative Addition of Methyl Iodide to a New Type of Binuclear Platinum(II) Complex: A Kinetic Study. Inorg. Chem. 2005, 44, 8594-8601. [CrossRef]

79. Aghakhanpour, R.B.; Nabavizadeh, S.M.; Mohammadi, L.; Jahromi, S.A.; Rashidi, M. A kinetic approach to carbon-iodide bond activation by rollover cycloplatinated(II) complexes containing monodentate phosphine ligands. J. Organomet. Chem. 2015, 781, 47-52. [CrossRef] 
80. Crabtree, R.H. The Organometallic Chemistry of the Transition Metals, 6th ed.; John Wiley \& Sons, Inc.: Hoboken, NJ, USA, 2018; pp. 155-156.

81. Maksić, Z.B.; Kovačević, B.; Vianello, R. Advances in determining the absolute proton affinities of neutral organic molecules in the gas phase and their interpretation: A theoretical account. Chem. Rev. 2012, 112, 5240-5270. [CrossRef]

82. Grummt, U.W.; Erhardt, S. Torsional profiles of protonated and metal-coordinated 2,20-bipyridine. J. Mol. Struct. 2004, 685, 133-137. [CrossRef]

(C) 2020 by the authors. Licensee MDPI, Basel, Switzerland. This article is an open access article distributed under the terms and conditions of the Creative Commons Attribution (CC BY) license (http://creativecommons.org/licenses/by/4.0/). 